صورة الطقل الفنية فى الثعر السعودى المعاصر

حمد فهر جنبان القحطانى

الملخص

تتاول البحث صورة الطفل الفنية فى الشعر السعودى المعاصر، وذلك من خلال

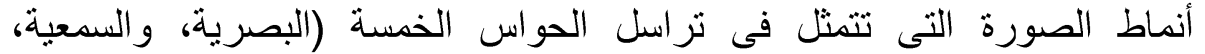

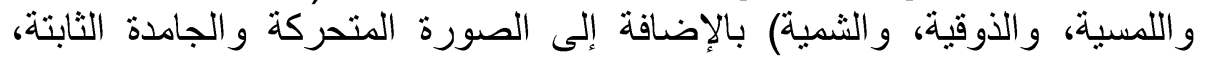
وكثفت عمق الصورة المفردة و الكلية.

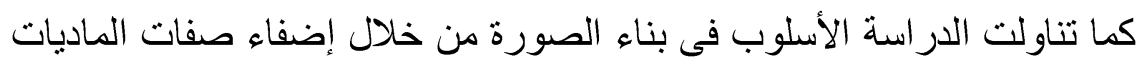

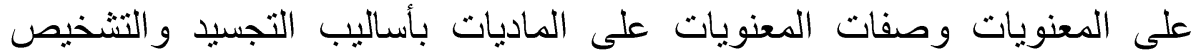
و التجريد، وذلك فى إطار ما قيل فى الطفل عند الشعر اء المملكة العربية السعودية. 
The Image of children in contemporary saudi Poetry

\title{
Hamad Al-Kahtani
}

\begin{abstract}
This research studies the image of children mediated by sensual figures 'visual rauditory ‘tactile 'Alfactory and gustative .It also examines static as well as dynamic images and individual as well as collective ones .It focuses on different stylistic modes of personifications 'materialzation and abstraction in saudi poetry.
\end{abstract}




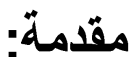

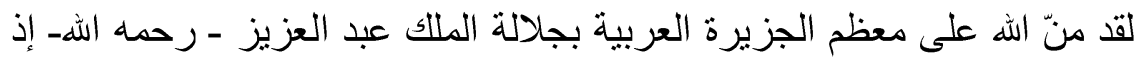

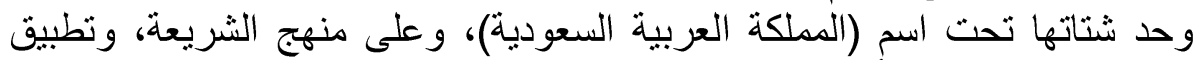

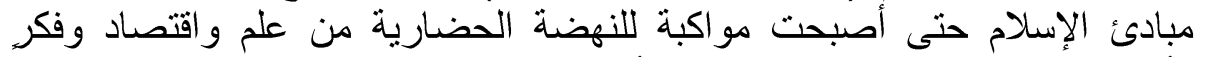

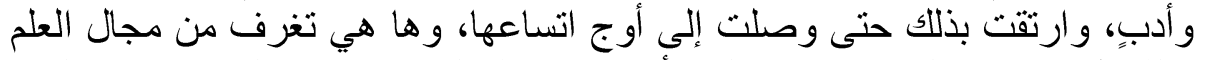

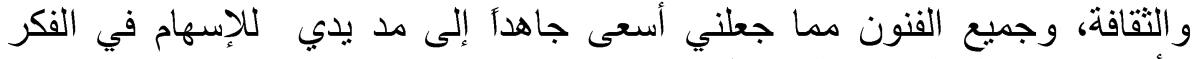
الأدبي من خلال البحث و والدر استة.

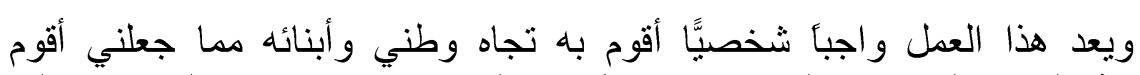

بدراسة الشعر السعودي المعاصر ساعياً في البحث عن موضوع لم لم تسبق إليه دراسة.

وللطفل مكانة مهمة في الدين الإسلامي جعلتني أكتب عنه در اسة مستقلة تحت اسم (صورة الطفل الفنية في الشعر السعودي الإنة المعاصري جملئ ).

إذ لم يحظ بدر اسة مستقلة إلا ما جاء على شكل مقالات قليلة لا تشكل در اسة فنية

حقبقية وجادة.

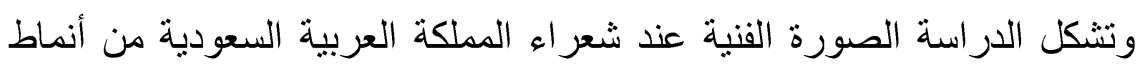

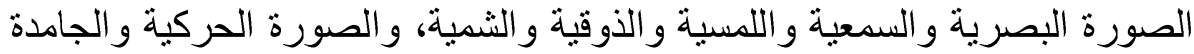
الثابتة، و -أيضا- المفردة والكلية، و الأسلوب في بناء الصورة ون والكنة تشخيص وتجسيد

$$
\text { وتجريد. }
$$

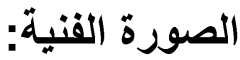

في الحقيقة إن الصورة القنيـة أهم المقومـات التي يقوم عليها الثـعر منذ القدم؛ وذلك بجانب الإيقاع الموسيقي و غير ها من بقية المقومات المتية.

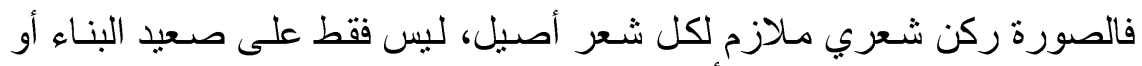

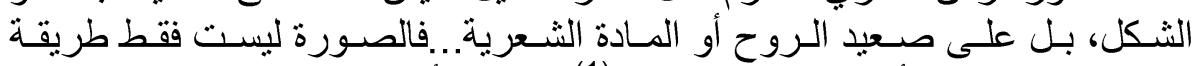

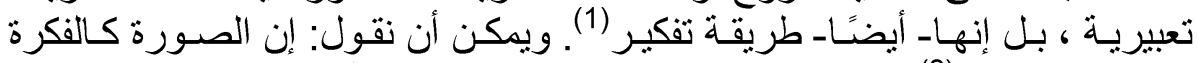

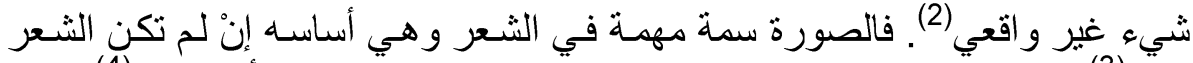

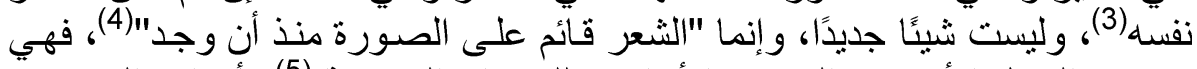

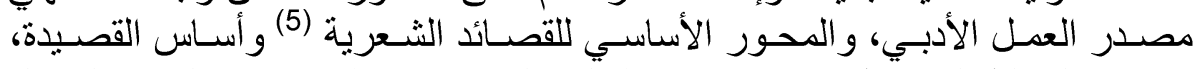

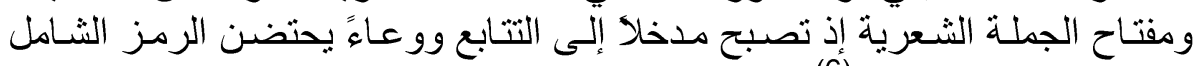

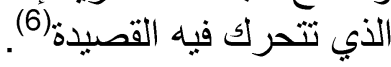

ويمكن أن نقول: إن الصـورة هي إبداع فني لتركيب لغوي يقوم على الخيال 


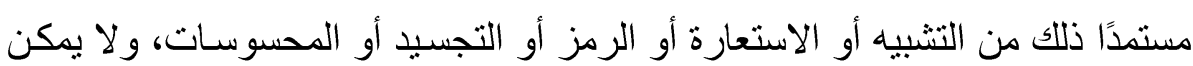
إغفال الصور النفسية والعقلية، وتوصيل التجربة الثعرية إلى الآخر.

\section{أولاً: أنماط الصورة الحسية:}

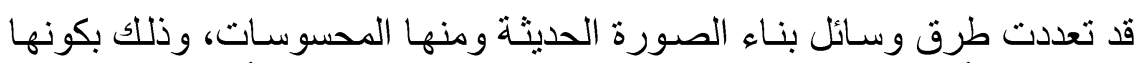

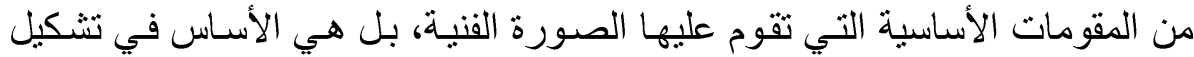

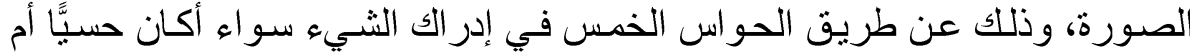

وقد توصل علماء النفس إلى هذه الأنماط من المحسوسات، وما إليها من الأنماط

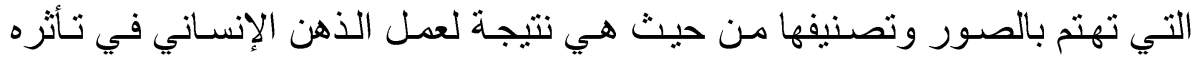

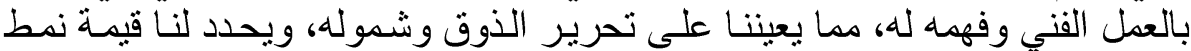

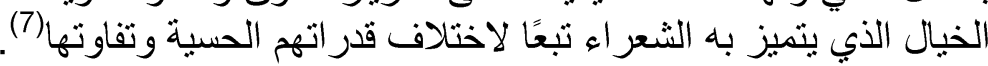

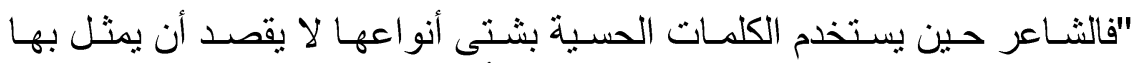

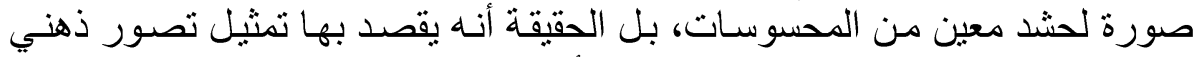

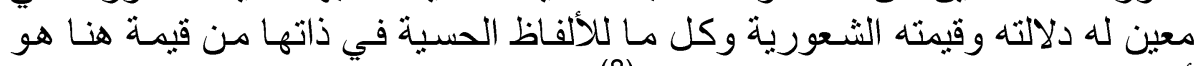
أنها وسيلة إلى تنشيط دلاله وضئه الحو اسع و إلهابها" (8)

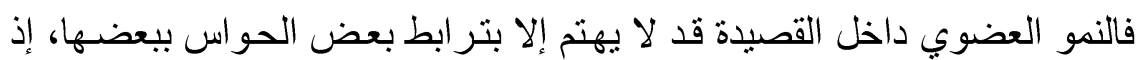

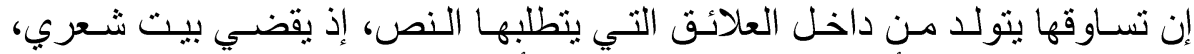

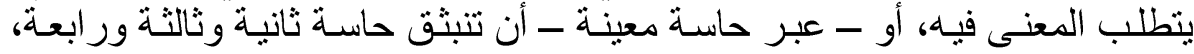

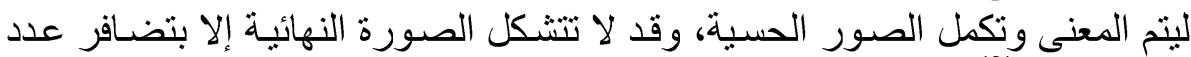

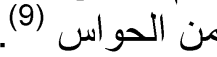

ولقد لاحظ النقاد علاقة الصورة بمدركات الحس، وقدرتها المتمبزة على مخاطبة

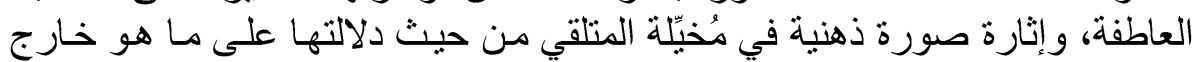

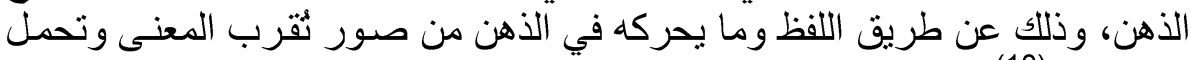
الإحساس (10).

وقد تؤلف العناصر الحسية قاعدة الانطلاق في تشكيل الصورة عند أي شـاعر؛ لأن الحس أساسه المعرفة (11)

فيمكن القول: إن النمط الحسي هو "الذي يربط مـادة الصـورة بالقاعدة النفسية

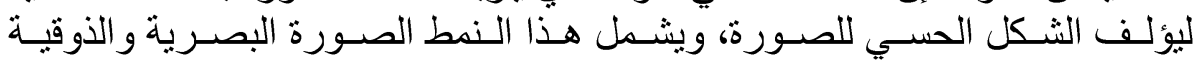

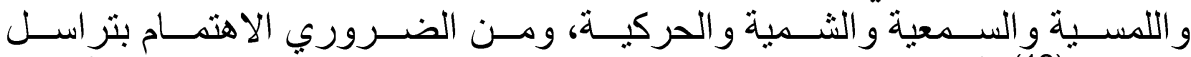

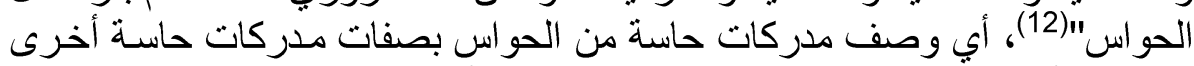

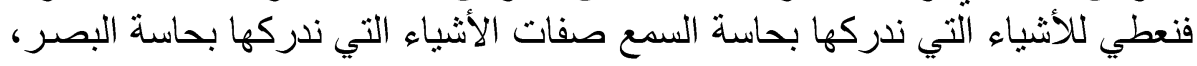


ونصف الأشياء التي ندركها بحاسة الذوق بصفات الأشياء التي ندركها بحاسـة الشـ،

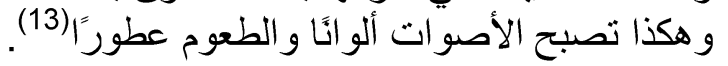

\section{1- م- الصورة البصرية:}

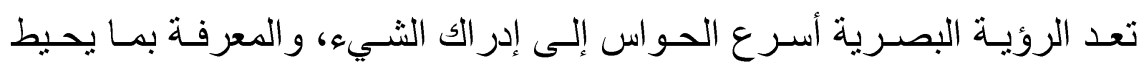

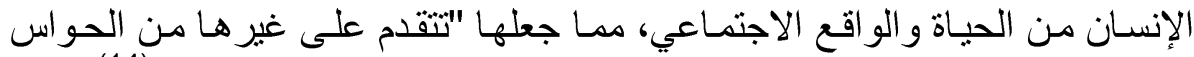

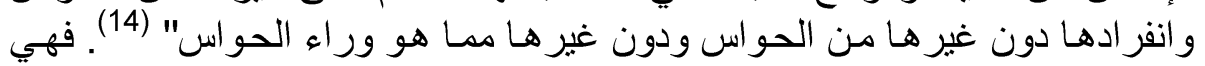

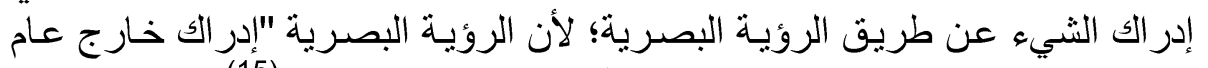

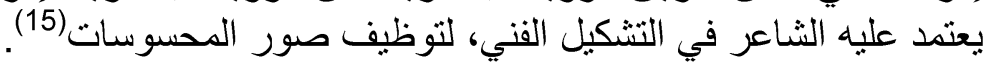

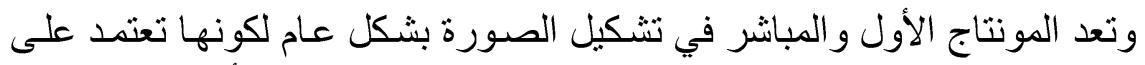

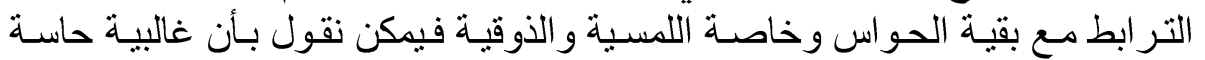

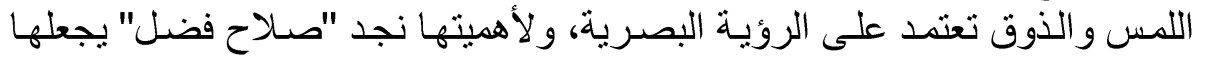

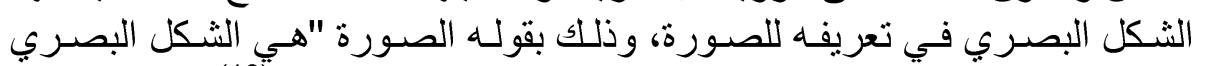

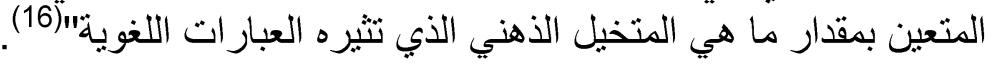

$$
\text { ومن هذه النماذج ما قاله "حمد العسعوس" في ابنه (أيمن): }
$$

(17) نيبّة: الـ بــــــــ

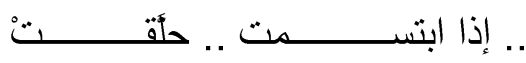
فالثـاعر يصور ابتسـامة ابنه، وهي صورة بصرية حركية، يرى فيها الثـاعر

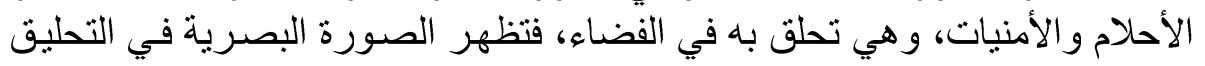

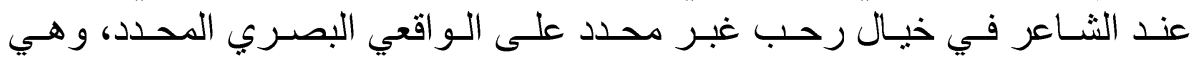
والإبتسامة عند الابن.

$$
\text { ويقول "الحازمي" في ابنه: }
$$

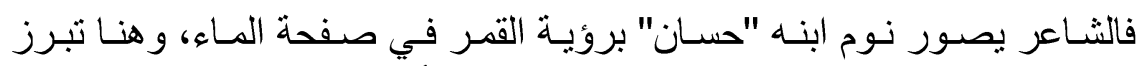

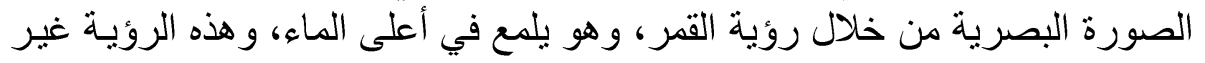
متحركة، و إنما ثابتة إلى حد ما.

$$
\text { ومن الصور البصرية قول "حبيب بن معلا " في ابنته (لجين): }
$$

(18)

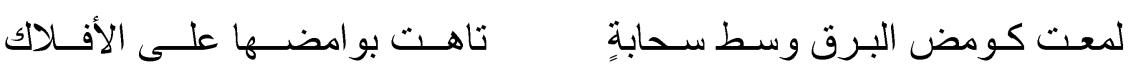
وقوله: 
حمد فهد جنبان القحطانى

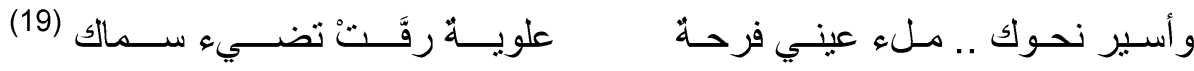

فالصورة البصرية في هذين البيتين؛ تبرز من خلال اللمعان و الومض و البرق

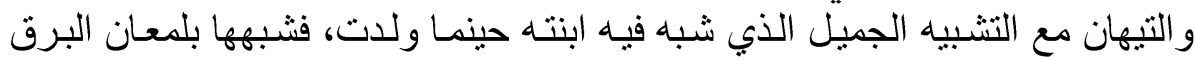
وسط السحابة، وفي البيت الثاني تبرز الصدورة البصرية من خلال العلو و الرفرفة، التهان

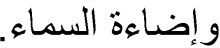

ويقول "عبدالله بن سالم الحميد" في ابنته "لمياء":

وابتســام اللؤلـــؤ / البــرق الــــي

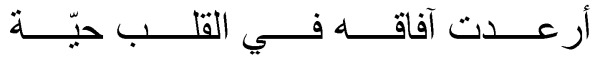

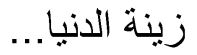

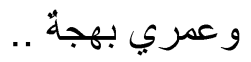

إن تر اءى طيف (لميـاء) البهيـة... (20)

فالصورة البصرية تظهر من خلال وصف الثناعر ابتسامة ابنته باللؤلؤ و البرق البرق

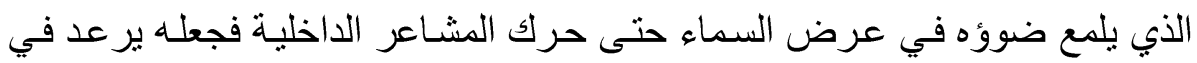

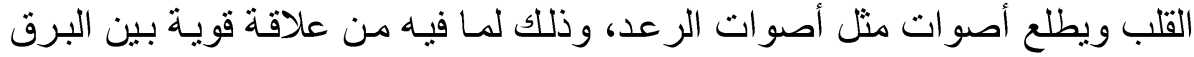

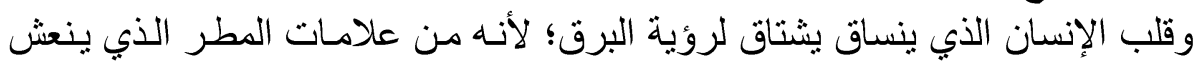

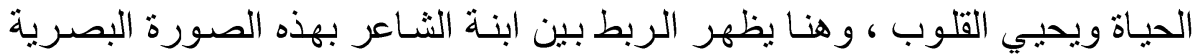

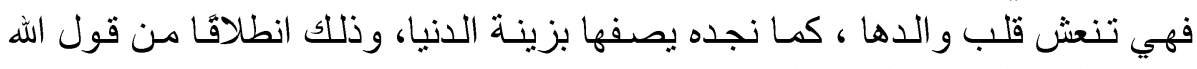

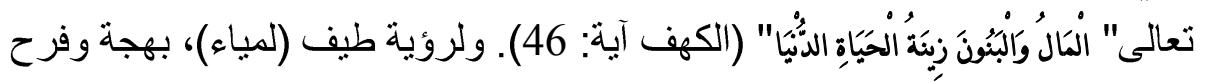

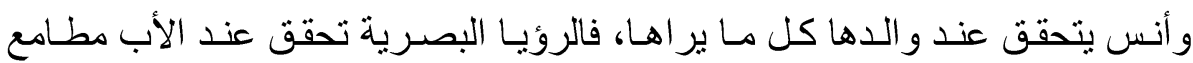

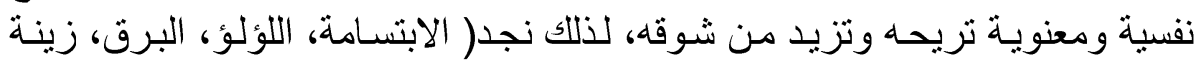

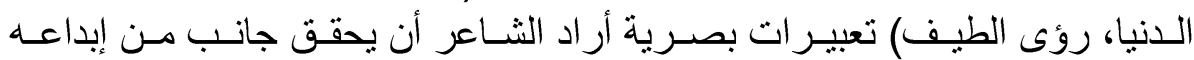

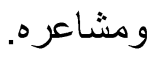

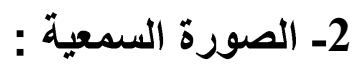

حوليات آداب عين شمس - المجلد 40 (يوليو - سبتمبر 2012) 
تعد الصورة السمعية الحاسة الثانية بعد البصر من خلال رسم الصسورة وبيانها،

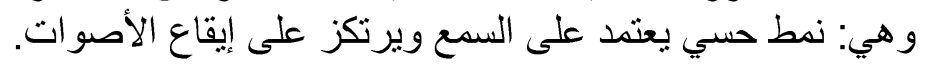

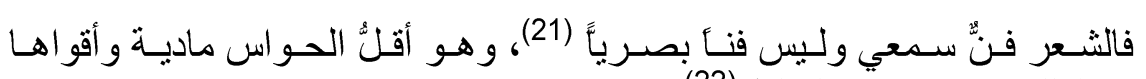
استخدامأ للرمز و الإشارة العقلية (22).

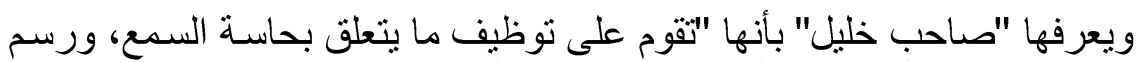

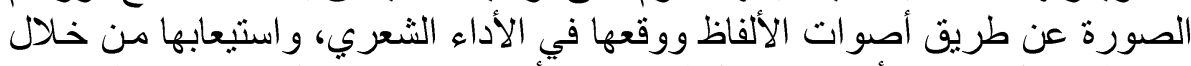

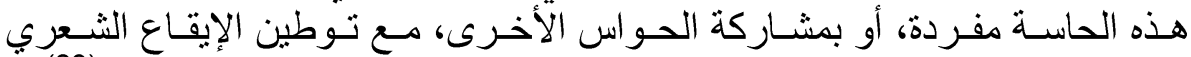

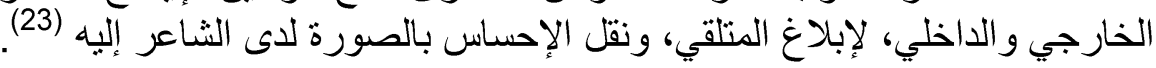
وستظهر لنا هذه الصورة بشكل واضح من خلال النماذج التالية : فيقول "طاهر زمخشري" عندما زف إليه نبأ ولادة حفيده "زهير":

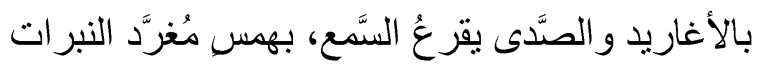
تتهادى به إليَّ التباثير، وتعطي الأفر اح بالبسمات (24).

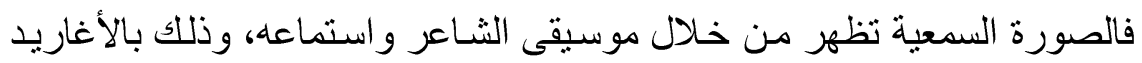

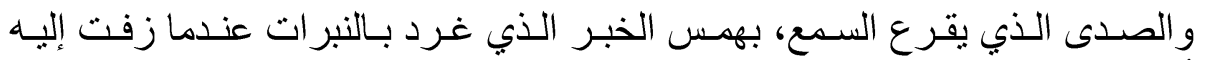

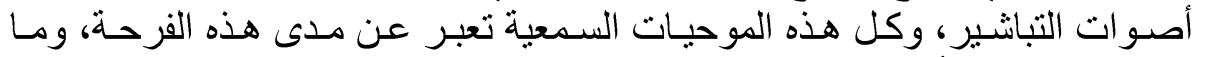

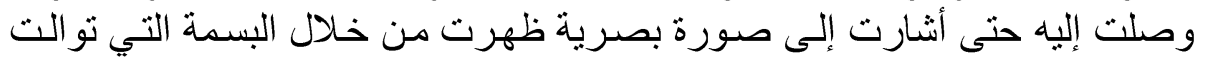
على الثناعر ور آها الآخرون. أنهارت و هذا "حمد العسعوس" يقول:

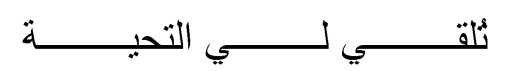

(25): ش كنغــ

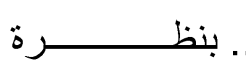
و أنتش

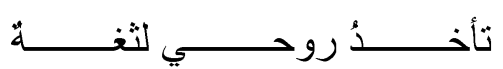

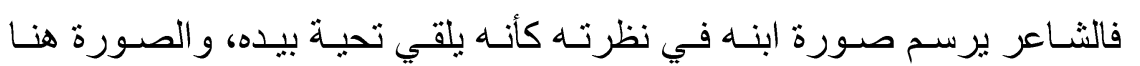

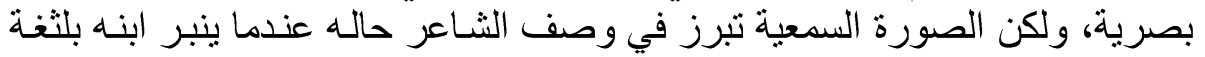
من فيه التي شبهرها بالنغمة الثجية.

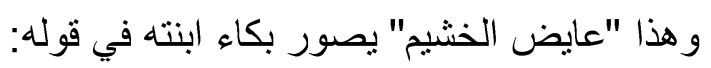

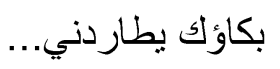
في كل حجرة تألمك يقض مضجعي يا مسكينة 


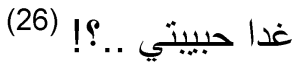
فتبرز الصورة السمعية عند الثاعر من خلال بكاء ابنته، ومطاردة صوت البكاء البكاء

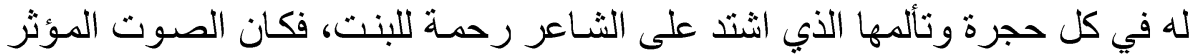
الأول حتى إنه يتجاوز الرؤية البصرية بعض النته الأحيان.

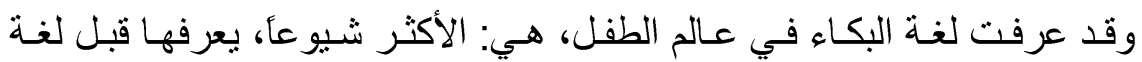

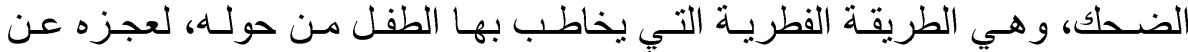
الكلام، وبهذه اللغة يعبر عن حاجاته الأساسية من الطعام و الرعاية و المصـاحبة، وكذا الماتها

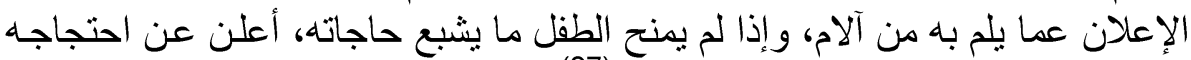

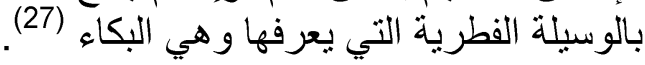
ويقول "حسن الزهر اني": عصفورتي سحر ترنمي و غردي بأعذب الألحان قولي أبي يا حلوتي بصوتلك الرنان

فطالما اشتاقت لها من ثغرك الآذان (28)

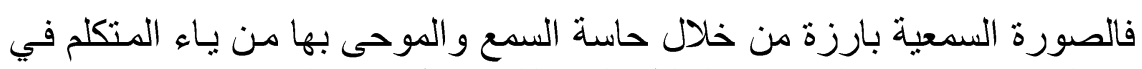

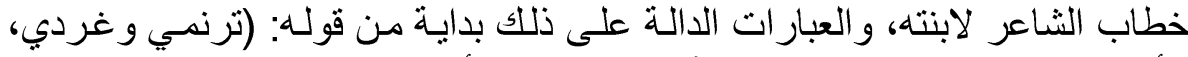
الألحان، قولي، بصوتلك، الرنان، الآذان)، فالمقطع بأكمله صورة سمعية.

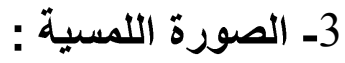

هي التي لا يمكن التوصل إلى بعض خصائصـها الذاتية التي تحصل بهـ الإنها

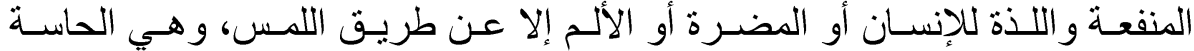

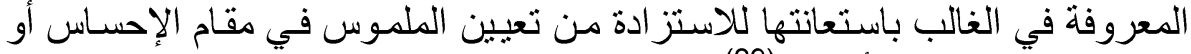
التلذذ به في الحواس الأخرى (29)

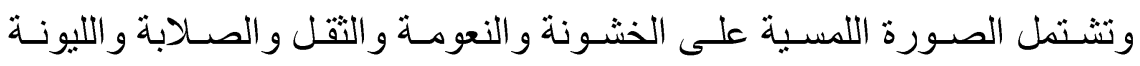
و الحرارة والبرودة و الجرح و غير ذللك مما له علاقة باللمس. ومن النماذج الدالة على ذللك قول "حبيب بن معلا اللويحق": 
ـ و وإذا اقتربتُ علقت بالثر اك الذي

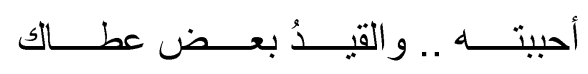

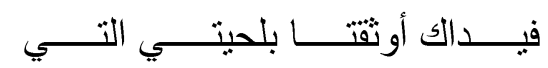

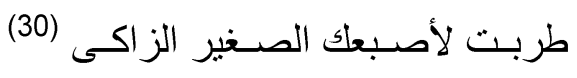

فالصورة اللمسية تظهر من خلال فوله: (علقتُ بالثر الك، و القيد، فيداك أوثيتا

$$
\text { بلحيتي، لأصبعك الصغير ). }
$$

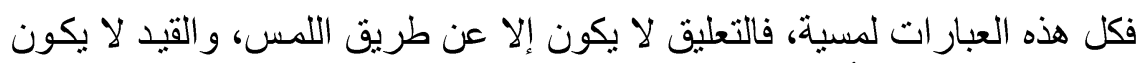

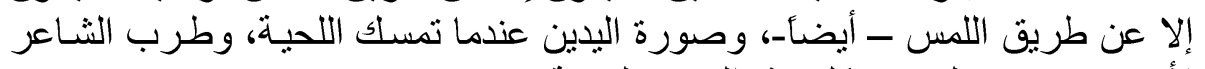
لأصبع صغيرته لجين، فكل هذه الصور لمسية.

$$
\text { واتذكر فبلاتلك الجميلة الخشيم": }
$$

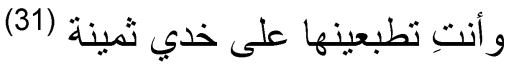

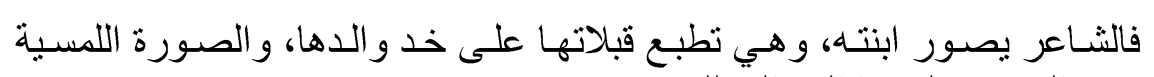

$$
\text { تبرز من القبلات ولمسها المتو الي للذد. }
$$

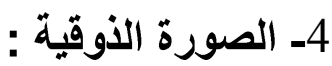

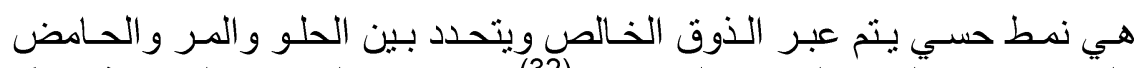

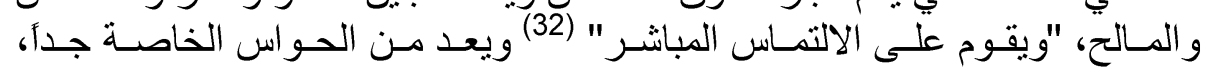

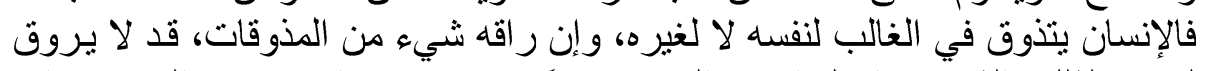

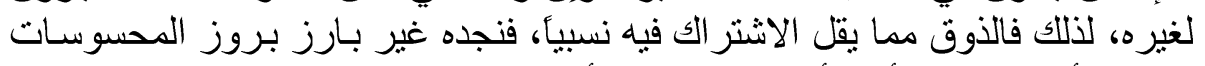

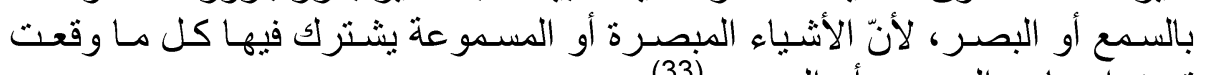

تحت إحساسه البصري أو السمعي (33). ويتضح ذلك عند "الحازمي":

يا ليتها في عبوني الآن تتسكبُ (34)

$$
\text { وأين ريقتهُ الـ "تتساب" في دعة؟! }
$$

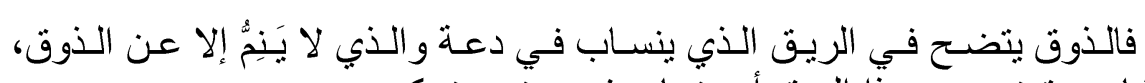
و الثناعر يتمنى، من هذا الريق أن ينساب في عينَه وينسكب. 


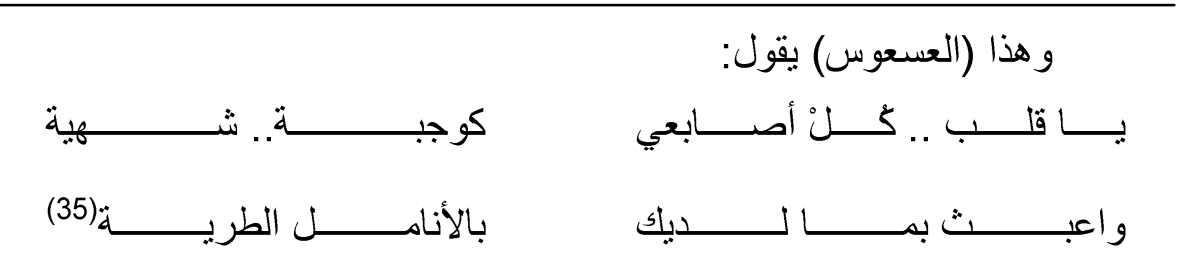

فالثاعر يخاطب قلبه بياء النداء ويشبه أصـابعه بالوجبـة التي طعمها لذيذ، وهنـا

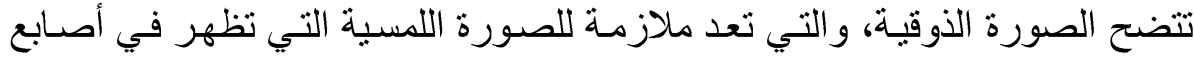
ابنه و عبثه بالأنامل الطرية.

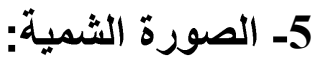

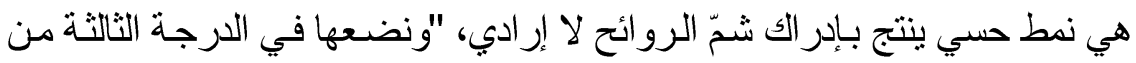

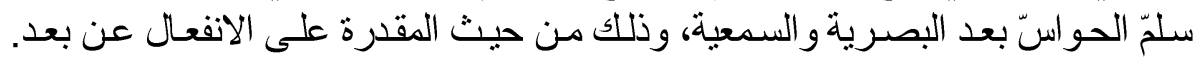

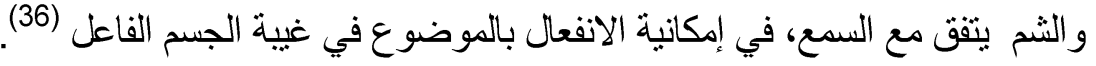

$$
\text { ويتضح ذلك في قول "زمخشري": }
$$

بالأز اهير ، وهي تتفح بالأنفاس "ميلاد" أكرم المعطيات (37)

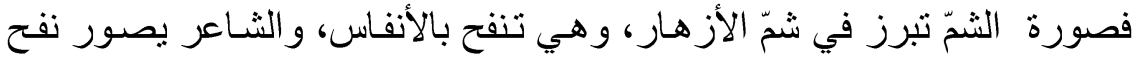

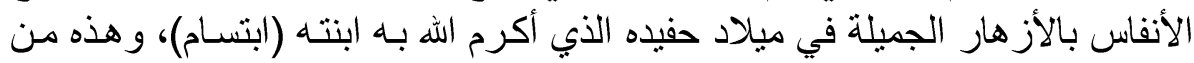
المعطيات التي تنفس بها الثناعر.

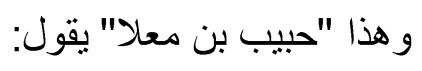

وشذاك أطيب من أزاهر روضةٍ

والريق أعذبُ من سوالك أرائ (38)

فالصورة الثمبة تظهر في تصوير الثاعر شذا ابنته، وجعله أطيب من أزهار

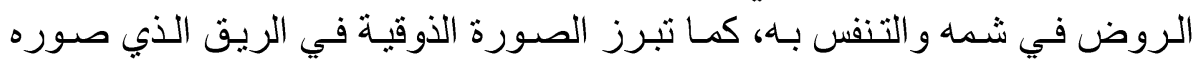

الثاعر بكونه أعذب من سو الك الأر اكل.

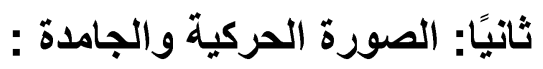

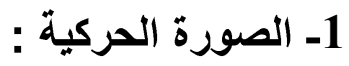




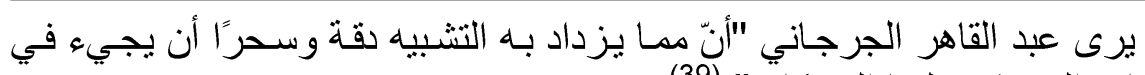

الهيئات التي يقع عليها الحركات" (39).

ويقول العقاد "إنمـا التصوير لـون وشكل، ومعنى وحركة، وقد تكون الحركة

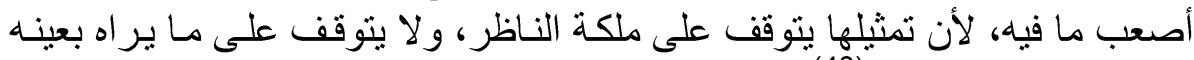

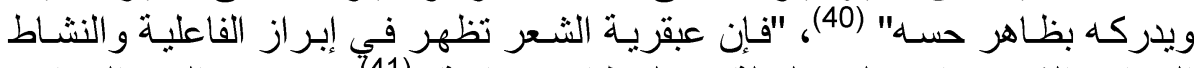

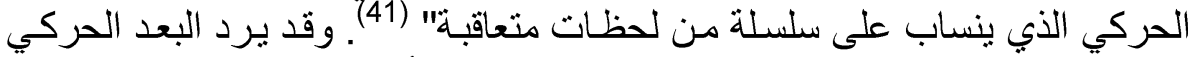

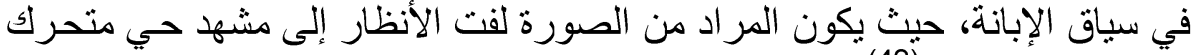
في الواقع المعيشي (42) في الإنة

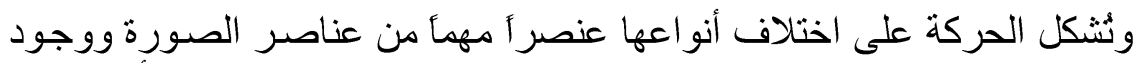

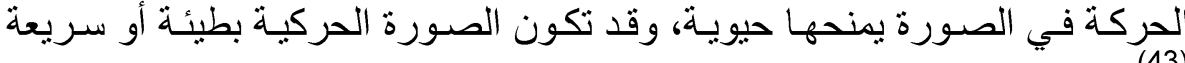

ومن النماذج الدالة على ذلك قول "الحازمي":

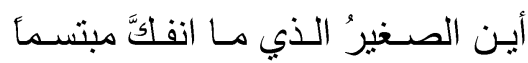

يجـــرُ خطو اتـــهـه نحــــوي ويضـــــربُ

$$
\text { يعـودُ، يــنهضن، لكـن لا تطاو عــه }
$$

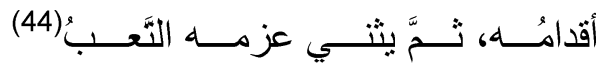

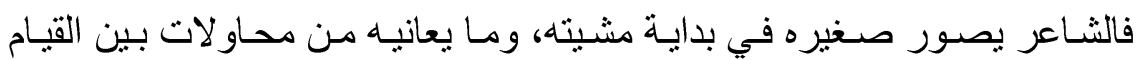

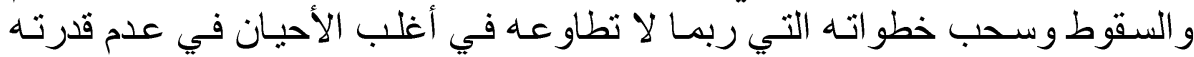

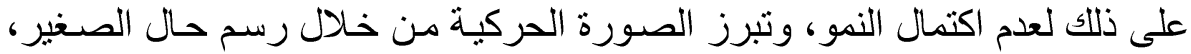

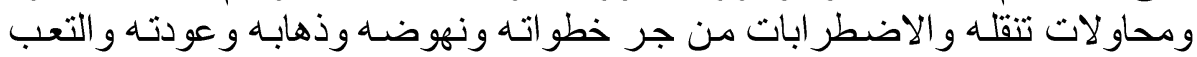
الذي يعانيه من خلات ذله ذلك.

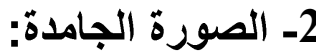

إلى جانب الصـورة الحركية نلاحظ صـور الجمود وهي تلك التي تهدف إلى التى

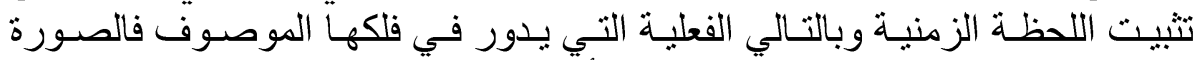

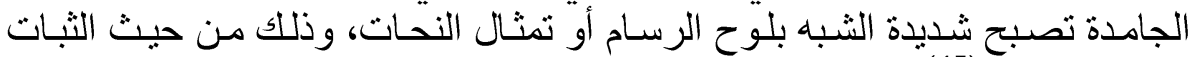
وتجاوز الزمن (45). وتؤكد طبيعة الصورة الثابثة الإلحاح على العنصر المكاني في الثـعر، و الاتكاء 
على البصر كآلة يتعرف بها الإنسان الأشياء (46).

ولعل خير مثال على ذلك قول "حسن القرشي" في تشبيه ابنه بالجبل في قوله :

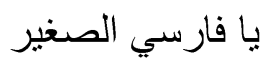

يا جبل تحرير الضمير والثعور يا صدحة الآمال في البكور (47)

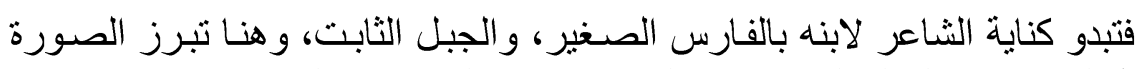
الثابتة الجامدة في الجبل الذي لا يتحرك ولاعيه يزيحه الهو اءه ولا الرياح.

ثالثًا: الصورة المفردة والكلية:

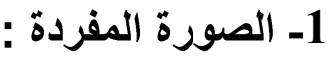

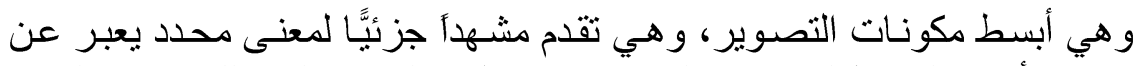

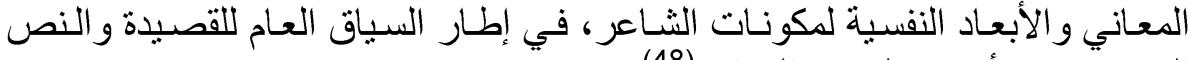
الشعري دون أن تتعزل عن السياق (48)

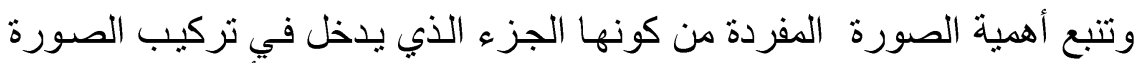

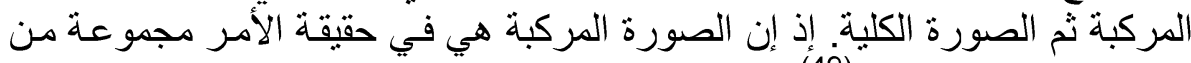

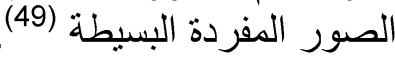

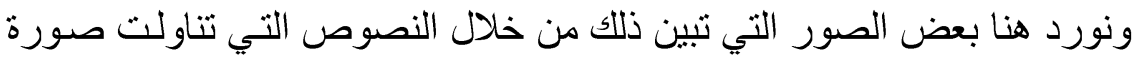
الطفل في الشعر السعودي، ومنهاً ما قاله "عبد الله الحميد" في ابنته (لَّيا):

طقلة..

أم وردة هذي البُنيّة

أم تر اها خفقة القلب الندية ؟!

وردة في القلب .. حاكت نبضه ..

شفتيها .. 


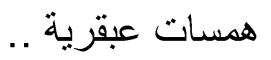

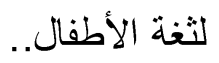

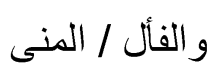

و البر اءات / الجميلات / الشجيّة (50)

فالصورة المفردة تظهر من خلال تشبيه الثـاعر ابتته بالوردة وتصويره هذه الوردة

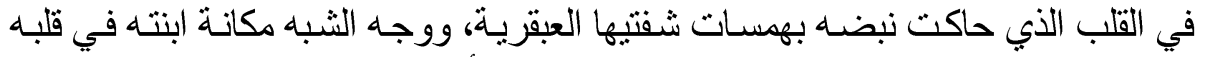

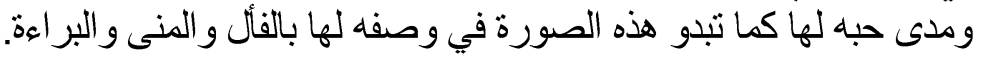

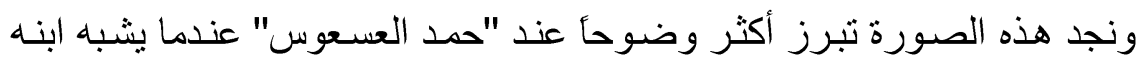

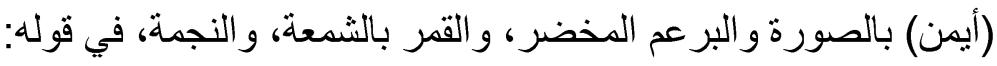

$\ddot{a}$

$$
\ddot{\alpha}
$$

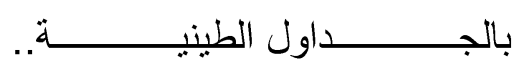

a

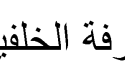
للثـ

(51) فـ ن ن

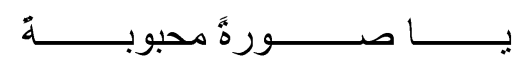

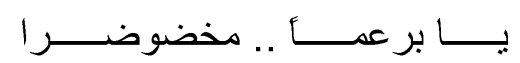

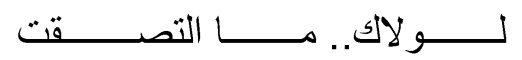

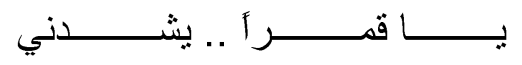

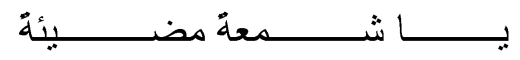

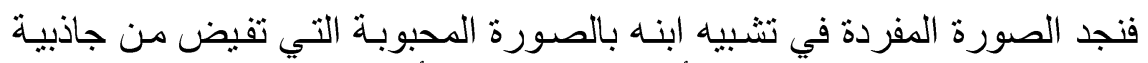

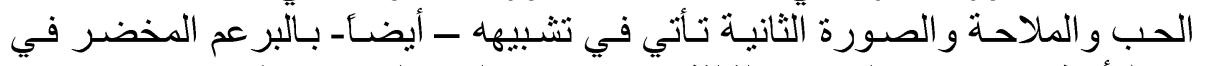

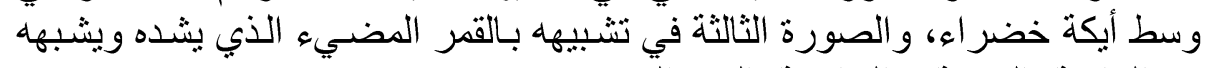
في الر ابعة بالثمعة، والخرة والضامسة بالنجم اللامع.

$$
2 \text { - الصورة الكلية : }
$$

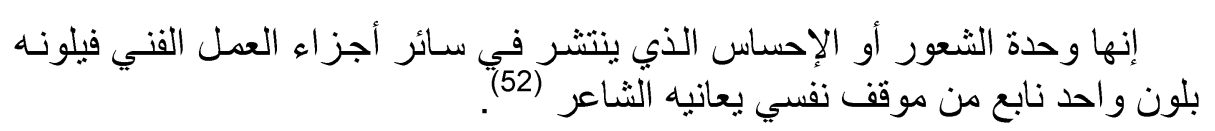

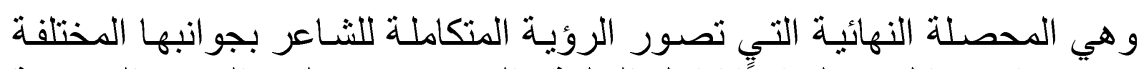

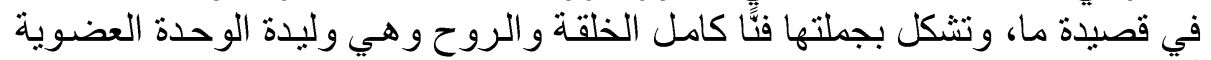

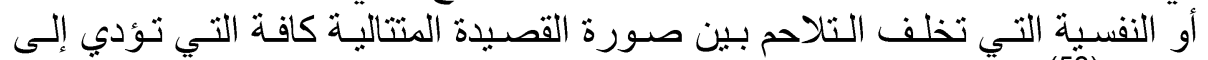
الكثف (53) 
ولعل قصيدة "حسن القرشي" التي بعنوان "ابنتي الصـغرى" خير مـا يمثل هذهان

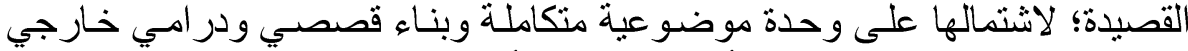

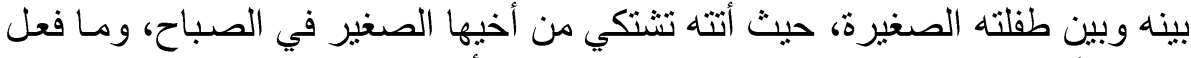
بإحدى دُماها الكثيرة، ويصور الثاعر طفلته حينما أتته تشتكي في فوله التهيه :

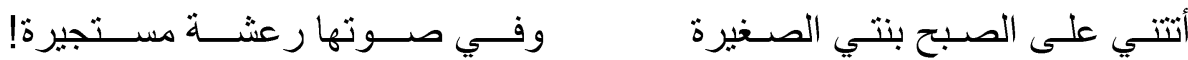

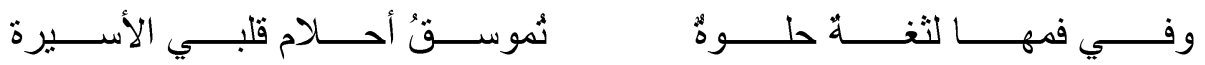

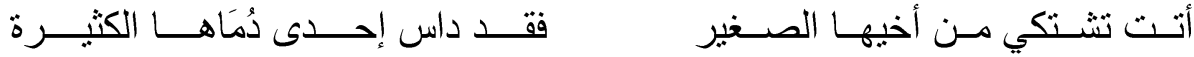

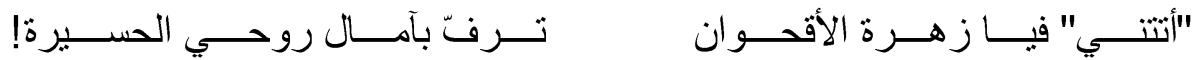

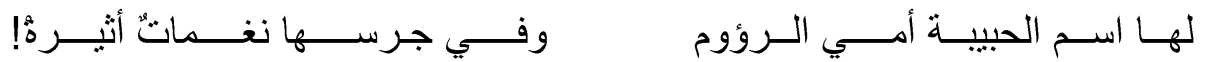

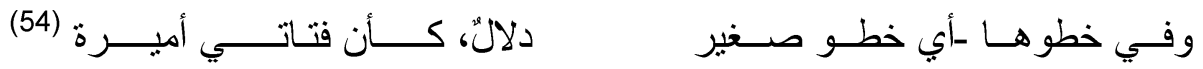

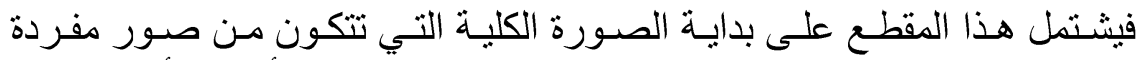

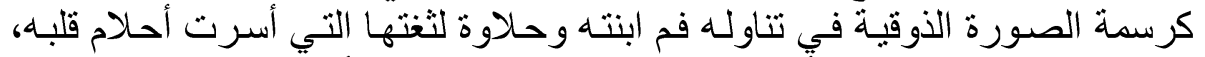

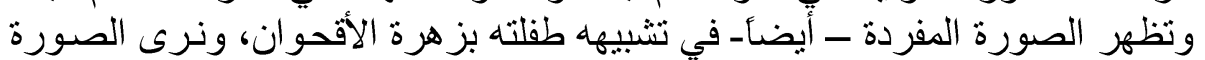

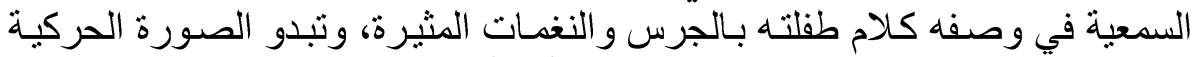
في تشبيه خطوات طفلته بالدلال الذي جعله بالها كأنها أميرة.

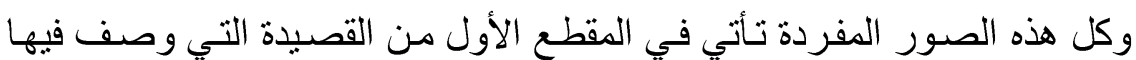
الثاعر مجيء ابنته وشكو اها إليه من أَخيها الصنغير. وفي المقطع التالي يأتي الرد من الأب على ابنته في قوله :

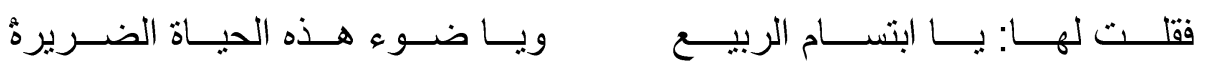

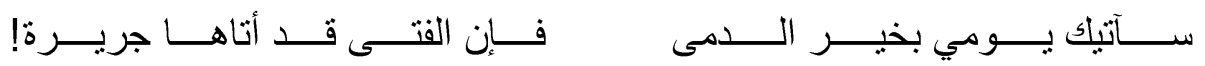

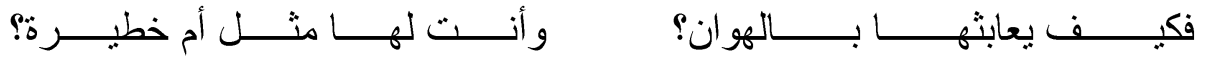

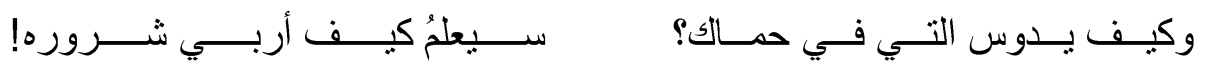




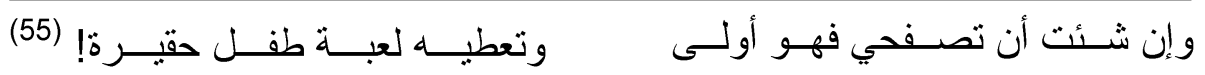

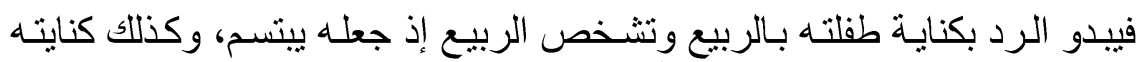

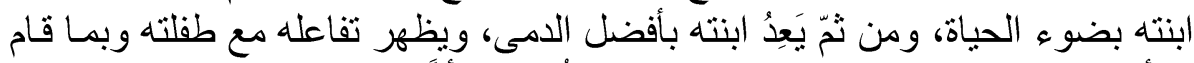

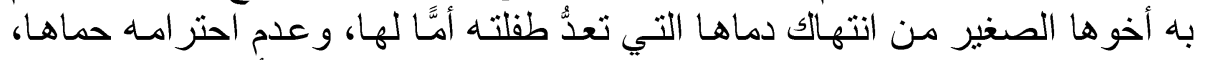

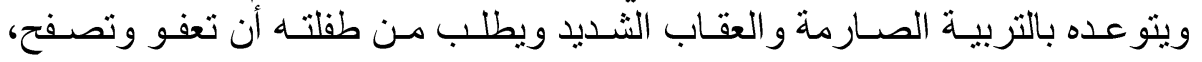
وتعطيه لعبة حفيرة.

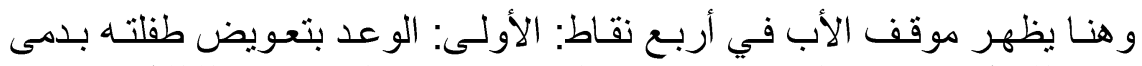

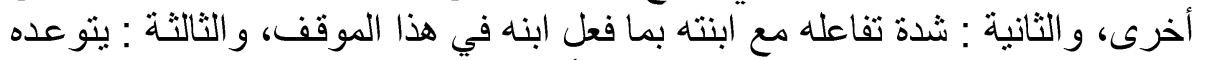

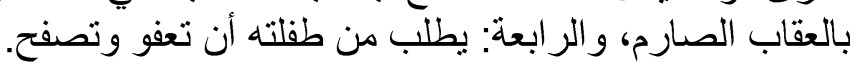
وفي المقطع الثالث يأتي الرد من ابنته في فوله :

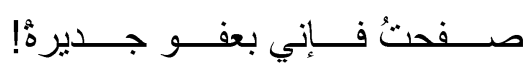

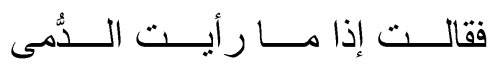

وإن كـنَّ مثــل الـتـلال الكبيـرة (56)

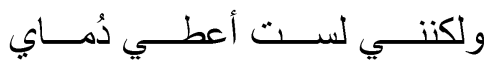

فتو افق الطفلة على العفو والصفح ولكن تشترط إحضـار دماهـا، وتؤكد بأنها لا تعطي ذُماها وإن كانت مثل الجبال الكبيرة.

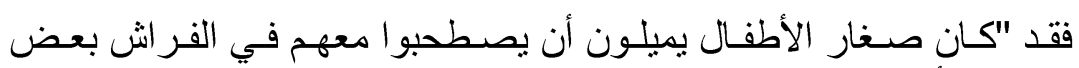

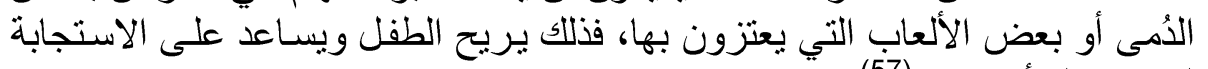

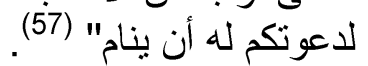
ويختم الثشاعر في المقطع الأخير بالدعاء لابنته بـالعيش في آمن وسـام لكونها كنز حياته الكبيرة.

لذا، تظهر الصورة الكلية في هذه القصبيدة من خلال الشكوى في المقطع الأول ومدى تفاعل الأب في المقطع الثًاني .

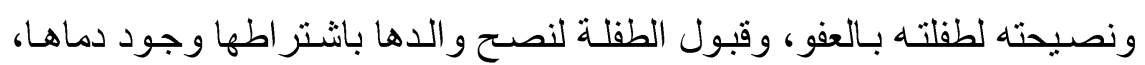

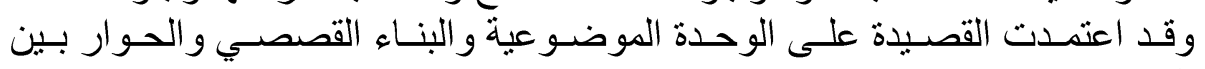
الشاعر و ابنته.

\section{رابعًا:الأسلوب في بناء الصورة :}

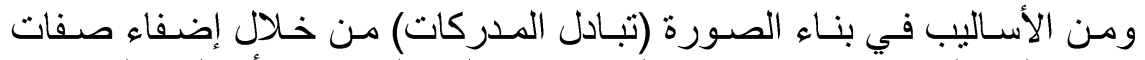

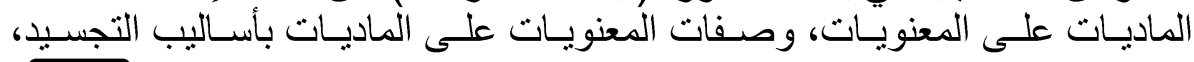


حمد فهد جنبان القحطانى

و التشخيص، و التجريد، وذللك للإيحاء بالأفكار و العو اطف بهدف التفيان التأثير (58).

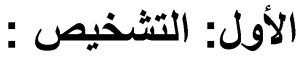

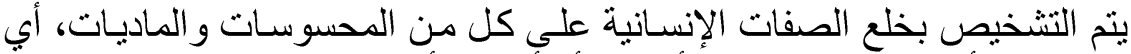

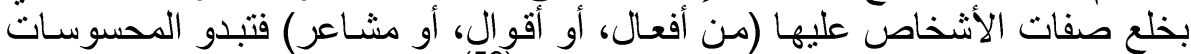

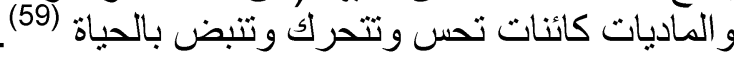

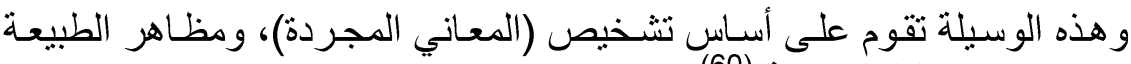
الجامدة في صورة كائنات حية (60) علون

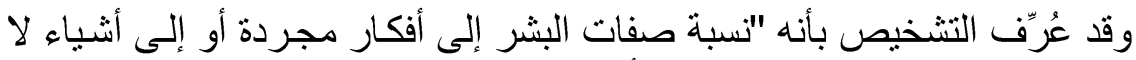

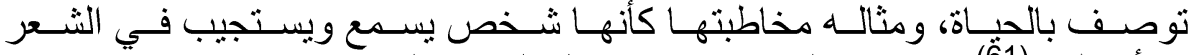
و الأساطير (61) هنا يبرز التشخيص من خلال النماذج الواردة.

$$
\text { فيقول "حسن القرشي" }
$$
لأحضن الهو اء حين تنهُ أعُ العبير

وتومض الدمع في عيني تشرق العصور (62)

$$
\text { من فمك الصغير }
$$

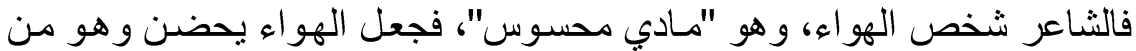

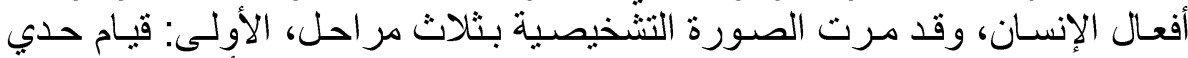

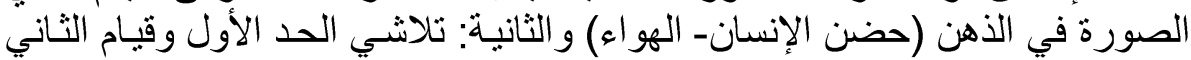

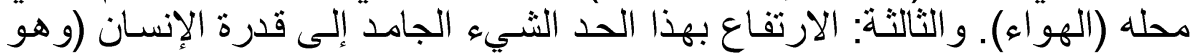

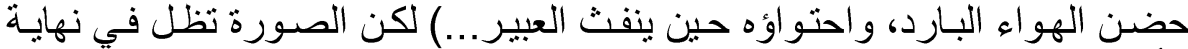

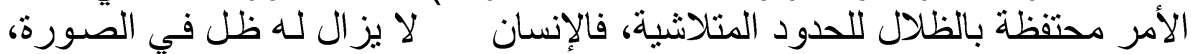

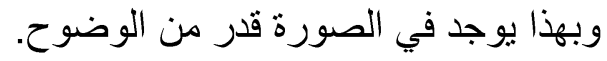

$$
\text { ومن ذلك قول" حسن الحازمي" في ابنه (حسان): }
$$

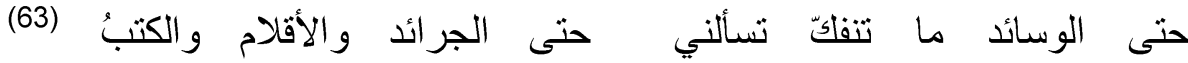
فالثشاعر يشخص الوسـائد، وهي ماديـة محسوسـة بالسؤال و الملاصقة في قولـه:

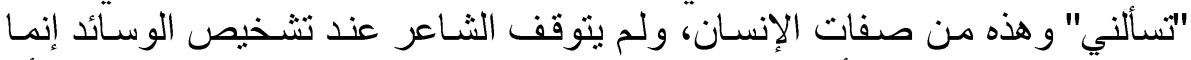

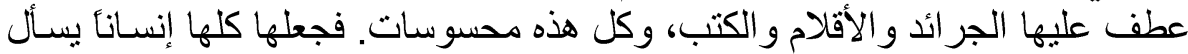

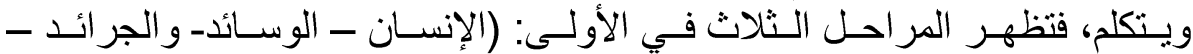

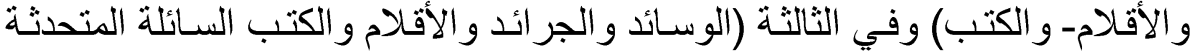
عن حال هذا الرجل مع طفله .... ). ويقول "علي الأمير" في ابنته "رامية" مدله 


$$
\begin{aligned}
& \text { فاستويتُ على منكب العيد } \\
& \text { أرقب هذا الهلال الجميل } \\
& \text { فينسى .. و أكبر } \\
& \text { يكبر .. أنسى }
\end{aligned}
$$

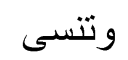

$$
\begin{aligned}
& \text { وتوقظني- عندما يلد الفجر فجر آ- } \\
& \text { يدار رامية (64). }
\end{aligned}
$$

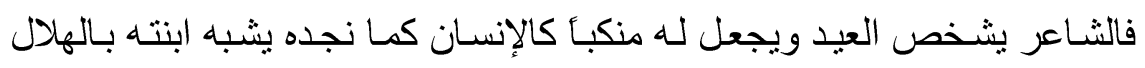

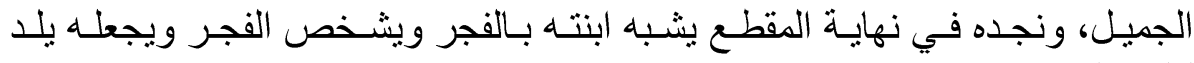
كالإنسان.

$$
\text { ومن ذلك قول "عبد الرحمن العمري" : }
$$

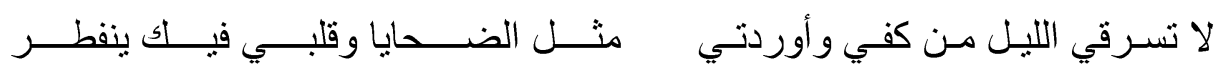

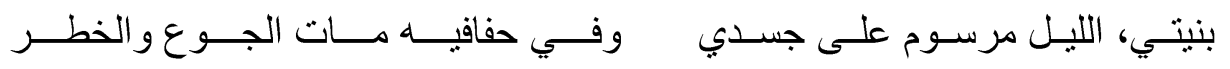
(65)

هـذه التجاعيد فـي خلـدي وأمنيتـي ســــابة هـــــــا الإمـــلاق و الســفر

$$
\text { وقوله: }
$$

مـا بـي إذا الصـبح أبـدى ناجذيـه وفي بعض مـن الليـل آهـات لمـن سـهروا

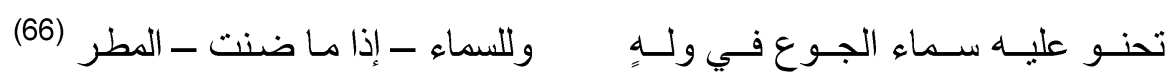

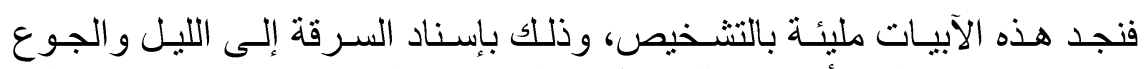

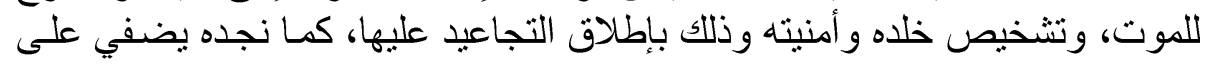
155 حوليات آداب عين شمس - المجلد 40 (يوليو - سبتمبر 2012) 


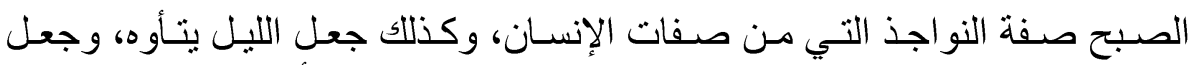

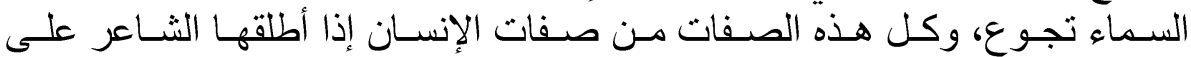

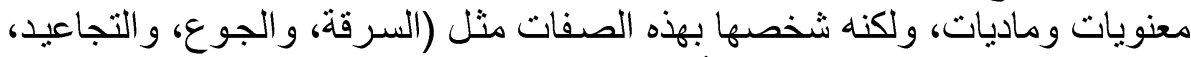
و النو اجذ، و الآهات، و والجوع ولكاته مرة أخرى).

الثاني: التجسيد :

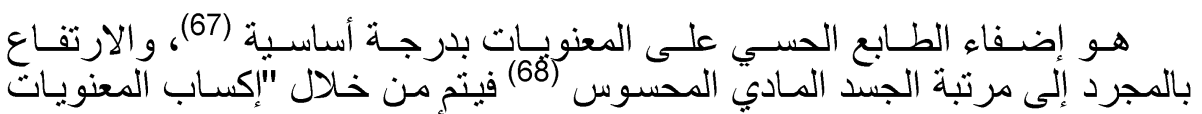

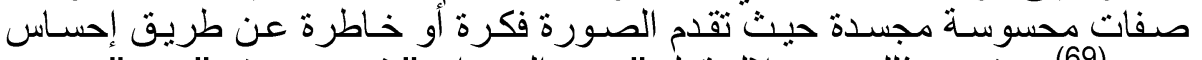

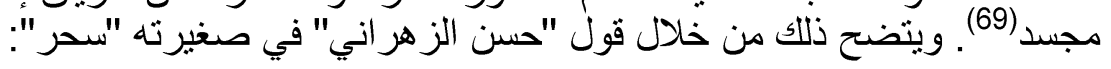

$$
\text { خذي حسام السعد واحكمي على أسابي بالإعدام }
$$

هزي جذور الفجر كي تهوي حنادس الظلام

مدي يديك و اغرسي فسائل السرور في مباسم الأيتام

تبسمي صغيرتي لتشرق الآمال في دروبنا

وتزهر الأحلام.. وتزهر الأحلام (70)

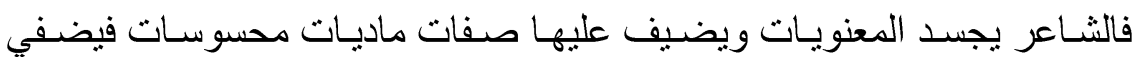

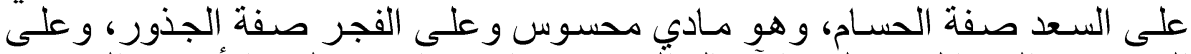

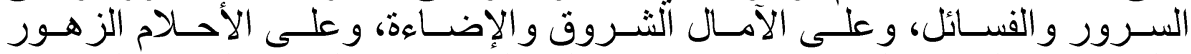

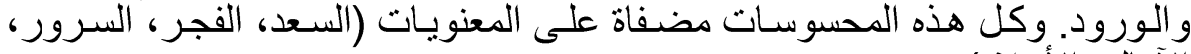

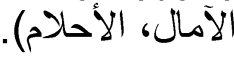

\section{ومن ذلك قوله في ابنه "عبد العزيز":}

أتيث ترسم شمس السعد في نظري

كما رسمت بنور الحب في خلدي (71)

فالثـاعر جسّد السعد وهو معنوي وأضفى عليه صفة محسوس وهو الثمس،

ونجد الثاعر يقول في نفس القصيدة :

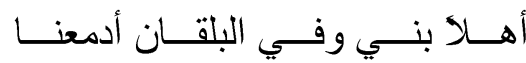

تسـاقطت فـوق صـرح الـذل كـالبرد (72)

فهو يجسد الذل وهو معنوي ويضفي عليه صفة محسوسة وهي الصرح القائم.

الثالث: التجريا : 
فيه (73) أن ينتزع من أمر ذي صفة أمرَ آخر مثله في تلك الصفة، مبالغة في كمالها والتجريــد في الصــورة هـو أن يجـرد الثــاعر مـن نفسـهـ أو مـن معنويـات أو محسوسات شيئَ يحاكيه (74) ونرى ذلك في قول "حسن الزهر اني" في ابنته "سحر": يا بسمة تغتال فجر الحزن (75).

يا نسمة تداعب الأوراق و الأغصان (76)

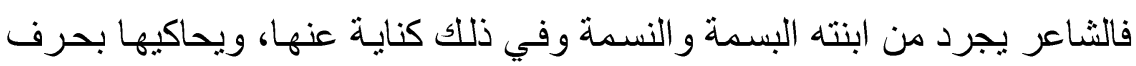

النداء (با).

كما يخاطب ابنته التي تعد جزء أ منه بقوله: كوني نهاية الخلاف بين خاققي وحَظه كوني حمامة السلام (77)

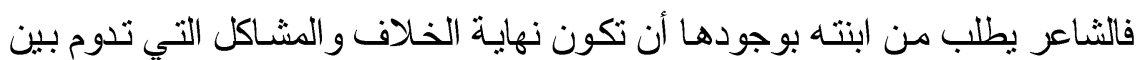

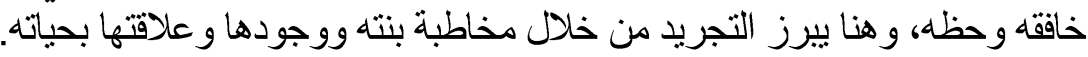

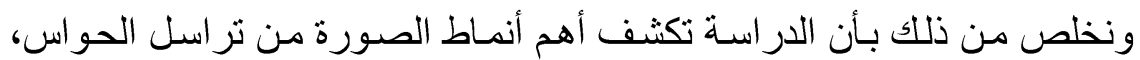

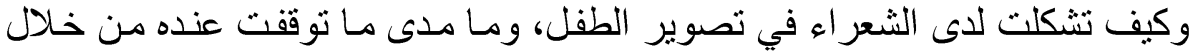

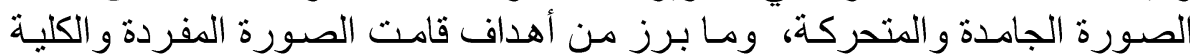

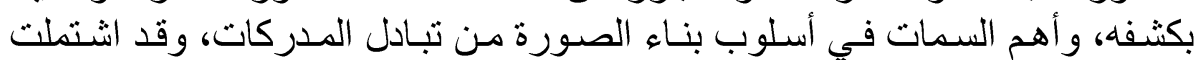
الدر اسة على تحقيق الغرض في جميع هذه الجوانب.

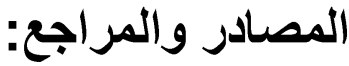

1 - ابن الرومسي حياتـه مـن شـعره، عبـاس محمـود العقار ، دار الكتـاب العربـي،

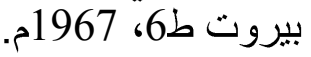

2 - الاتجاه الإسلامي في شعر محمد بن سعد الدبل، حمد فهد جنبان الخنفري،

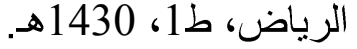
3 - أسرار البلاغة، عبد القاهر الجرجاني، دار المسيرة، بيروت، 1979م. 


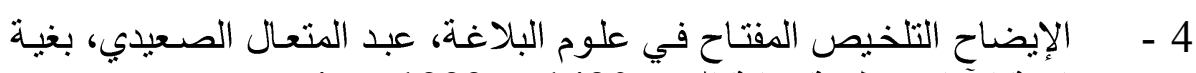

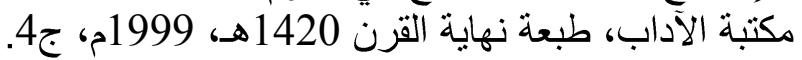

5 - إيمـان الكيلانـي، در اسـة أسـلوبية لشـعر بـدر شـاكر السباب، رسـالة دكتور اه

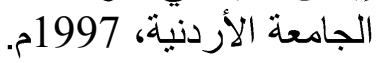

6 - بلاغـة الصـورة القر آنيـة الجماليـات و التحليـات، طـارق سـعد شـبلي، دار

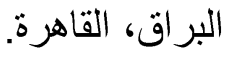
7 - - 1 8 - التجنيس وبلاغـة الصـورة، فخري صـالح، دار ورد، الأردن، ط1، مئ، 2008م.

9 - تطور الصـورة الفنبـة في الثـعر العربـي الحـيث، نعيم اليـافي، صـفحات

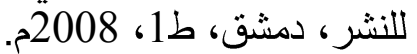

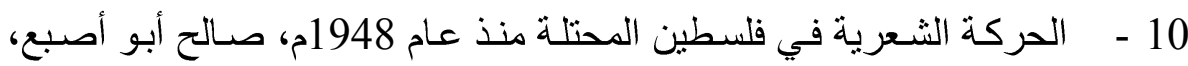

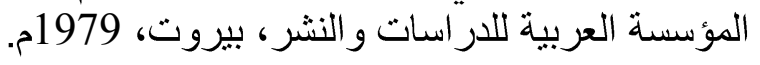

11 - حقوق الطفل، إسماعيل عبد الكافي، مركز الإسكندرية للكتاب، الإسكندرية 2005/1426

12 - خالد محادين حياته وشعره، نايل محمد الحجايا، مركز يزيد للنشر، الكرك،

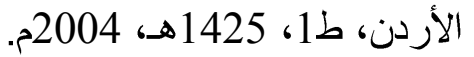

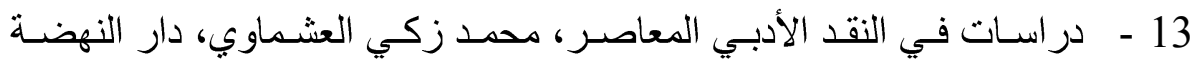

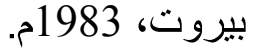

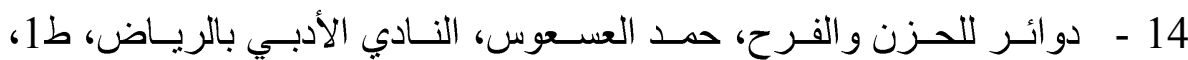
1986/1407م. دون

15 - رعاية الطفل من الجنين حتى عامين، كريمان بدير، عالم الكتب، القاهرة، ط1، 1424هـ، 2004م.

16 - السفر في ذاكرة الوطن عبداله بن سـالم الحميد، دار طويق للنشر والتوزيع،

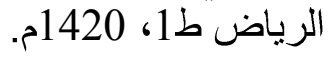

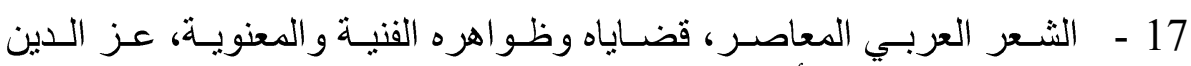

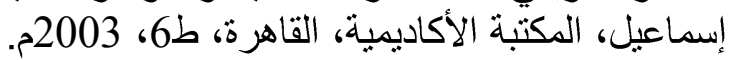
18 - شعر غازي القصيبي، در اسة فنية، محمد الصفر اني، ط1، 2006م. 
19 - شـعر اء مـن منطقة تبوك، نـايف الجهني، إشـر اف موسى العبيدان، النـادي

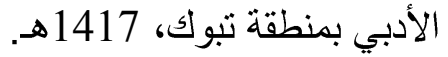

20 - صدى الأشجان، حسن محمد الزهر اني، النـادي الأدبي بالباحة، مطابع دار العلم، ط1، 1418هـ. - الن.

21 - الصـورة الاستعارية في الثـعر العربـي الحديث، وجدان الصـانع، المؤسسـة العربية، بيروت ط1، 2003م.

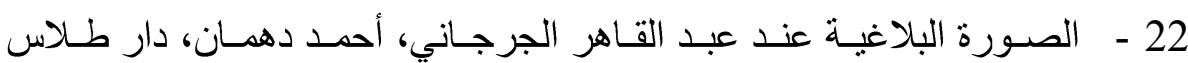
لللنشر، دمشق، ط1 البرغ، 1986.

23 - الصـورة السمعية في الثـعر العربـي الجـاهلي، صـاحب خليـل إبر اهيم، مـن

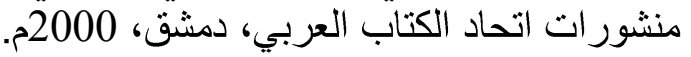

24 - الصـورة الشـعرية عند بـدوي طوقـان، خالد ســداوي، دار المشرق للترجمـة

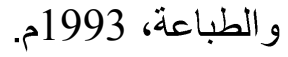

25 - الصورة الثـعرية في النقد العربي الحديث، بشرى موسىى صسالح، المركز الثقافي العربي، بيروت، ط1، 1994.

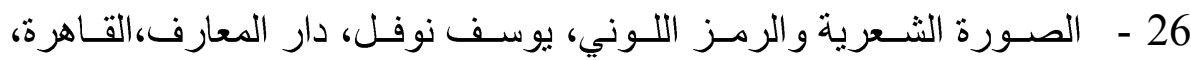

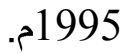

27 - الصورة الثعرية، ساسين سبمون عساف، دار مـارون عبود، بيروت، ط1،

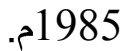

28 - الصورة الفنية عند النابغة الذبياني، خالد محمد الزواوي، الثـركة المصرية العالمية للنشر ، القاهرة، ط1، 1992م.

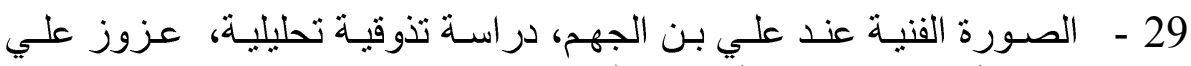

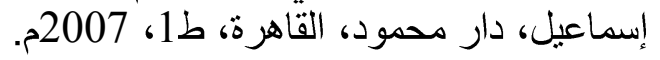

30 - الصـورة الفنيـة في الثـعر العربـي، إبـر اهيم عبد الـرحمن الغنـيم، الثـركة العربية للنشر، السعودية.

31 - الصورة الفنية في شعر الطائيين بين الانفعال والحس، وحيد صبحي كبَّابة، الصورة منشور ات اتحاد الكتاب العرب، دمشن، الصنق، 1999م.

32 - الصورة الفنية في شعر زهير بن أبي سلمى، عبد القادر الربـاعي، دار العلوم للطباعة والنشر، الرياض، فيرة 1984م. 
33 - الصـورة الفنيـة في شـعر علي الجـارم، إبر اهيم أمين الزرزمـوني، دار قبـاء

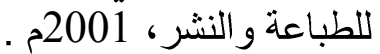

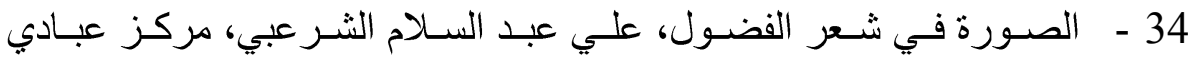

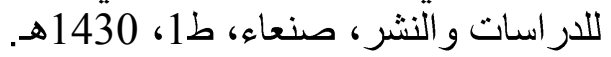

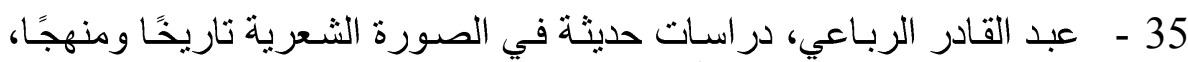

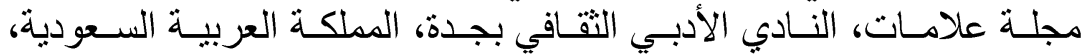

1994م.

36 - العصر الجاهلي، شوقي ضيف، دار المعارف، القاهرة، 1976م.

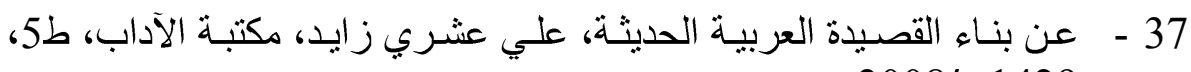
1429 هـ/ 2008)

38 - الديوان، العواد، دار العودة، بيروت، ط2، 1979م، جـ2.

39 - فن الثعر، إحسان عباس، دار الثقافة، بيروت، ط3،

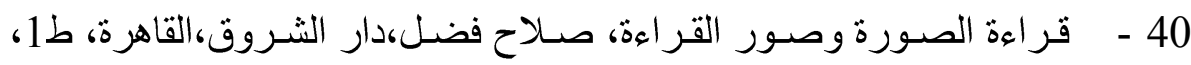

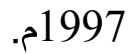

41 - مبادئ علم النفس العام، يوسف مر اد، دار المعارف، القاهرة، ط1، 1987م.

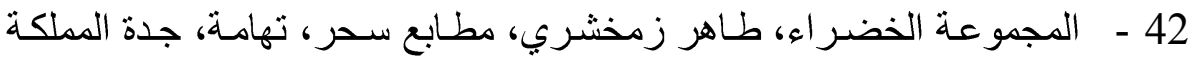

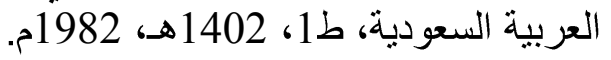

43 - معجم البلاغة العربيـة، بدوي طبانة، دار العلوم، الريـاض، المملكة العربيـة

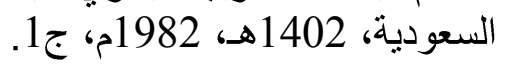

44 - نوافذ الثمس، حبيب بن معلا اللويحق المطيري، دار القاسم للنشر، الرياض

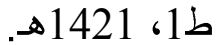

45 - همس الوجدان، عايض ناصر الخشيم، الرياض، ط1، 442هـ، 2001م .

46 - وردة في فم الحزن، حسـن منصـور الحـازمي، نـادي جـاز ان الأدبـي، ط1 1416، هـه

الصسورة الثعرية، ساسين سبمون عسـاف، دار مـارون عبود، بيروت، ط1،

1985م، ص صة 38 


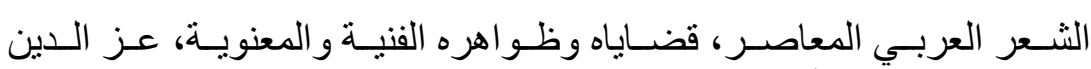

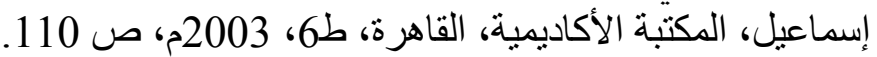

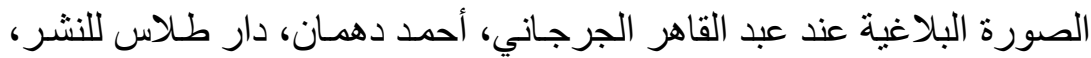

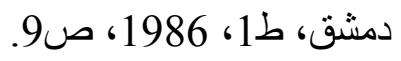

فن الشعر ، إحسان عباس، دار الثقافة، بيروت، ط3، 1983، 1983، ص 230.

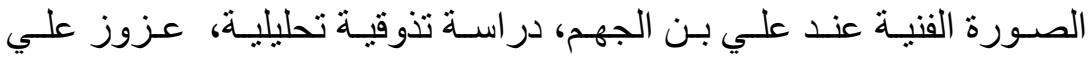

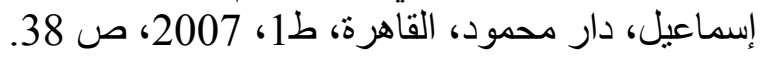
التجنيس وبلاغة الصورة، فخري صـالح، دار ورد، الأردن، ط1، طر، 2008، ص ص الصـورة الثـعرية في النقد العربـي الحديث، بشـرى موسـى صـالح، المركز

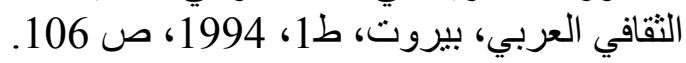

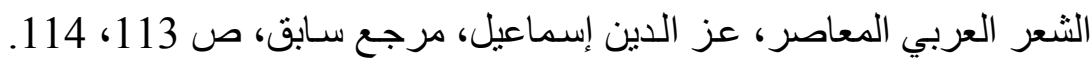

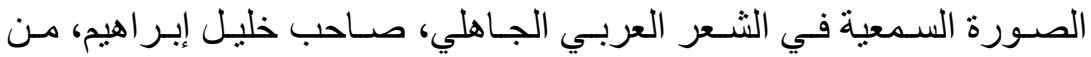

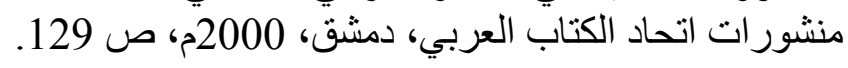

(10) الصورة الفنية عند النابغـة الذبياني، خالد الزواوي، دمئ، مرجع سـابق، ص 113. (11) الصورة الفنية في شعر زهير بن أبي سلمى، عبد القادر الرباعي، دار العلوم

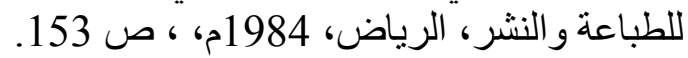

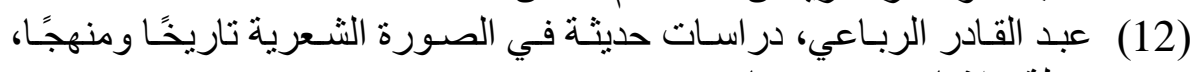

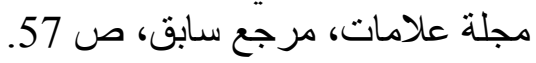

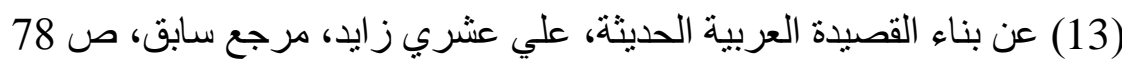

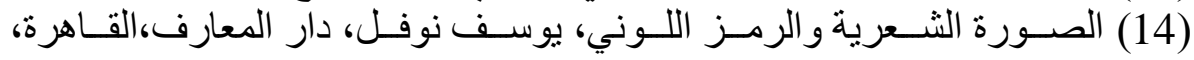
1995، 19 13 1الصورة الثعرية في النقد العربي الحديث، بشرى موسى صـالح،مرجع سـابق، (16) فـر اعة الصــورة وصــور القـر اعة، صــلاح فضـلـ،دار الثــروق،القاهرة، ط1،

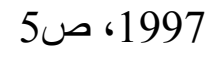
دوائر للحزن والفرح، حمد العسعوس، النادي الأدبي بالرياض، ط1، نو افذ الشمس، حبيب بن معلا اللويحق المطيري، دار القاسم للنشر، الرياض

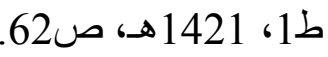

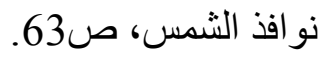


(20) السفر في ذاكرة الوطن عبداله بن سالم الحميد، دار طويق للنشر و التوزيع،

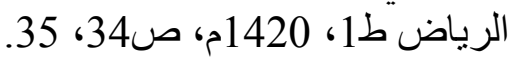

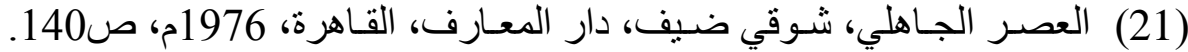

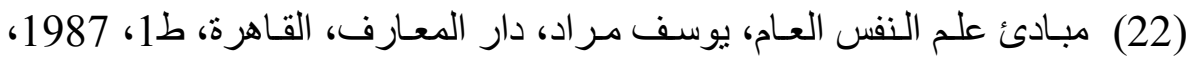
ص67.

(23) الصسورة السمعية في الثـعر الجـاهلي، صـاحب خليل إبر اهيم، مرجع سـابق،

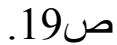

المجموعة الخضر اء، طاهر زمخشري، مطابع سحر، نهامة، جدة ــ المملكة

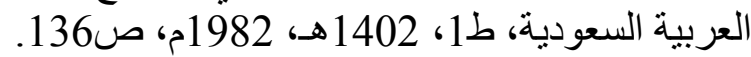

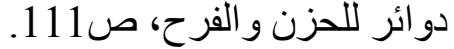

همس الوجدان، عايض ناصر الفر الخشيم، الرياض، ط1، 442هـ، 2001م ،

حقوق الطفل، إسماعيل عبد الكافي، مركز الإسكندرية للكتاب، الإسكندرية

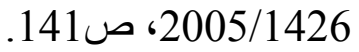

صدى الأشجان، حسن محمد الزهراني، النادي الأدبي بالباحة، مطابع دار

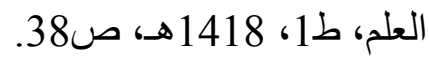

الصورة في شعر الفضول، على علي عبد السلام الثرعبي، مركز عبادي

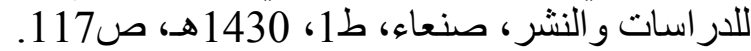
همس الوجدان، ص102.

مبادئ علم النفس العام، يوسف مر اد، دار المعارف، القاهرة، ط7، 1978م،

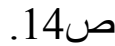
الصورة الفنية في الثعر العربي، إبر اهيم عبد الرحمن الغنيم، الثـركة العربية

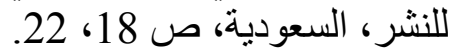

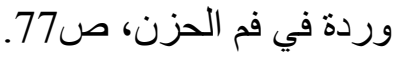

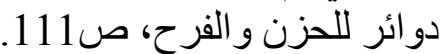

الصورة الفنية في شعر الطائيين، وحيدة صبحي كبابة، منشورات اتحاد

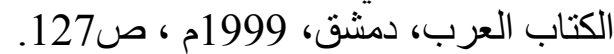

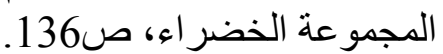

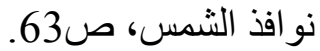
164 أسرار البلاغـة، عبـد القـاهر الجرجـاني، دار المسـيرة، بيـروت، 1979، ص 
(40) ابـن الرومسي حياتـهـ مـن شـعره، عبـاس محمـود العقـار ، دار الكتـاب العربـي،

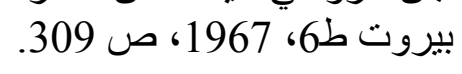

(41) شـعر غـازي القصـيبي، دراسـة فنيـة، محمــ الصـفر اني، ط1، 2006م، ص

(42) بلاغة الصورة القر آنية الجماليات والتحليات، طسارق سعد شبلي، دار البراق،

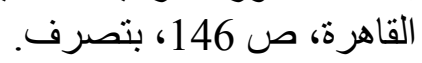

(43) الصـورة الفنيـة في شـعر علـي الجـارم، إبـر اهيم أمسين الزرزمـوني، دار قبـاء

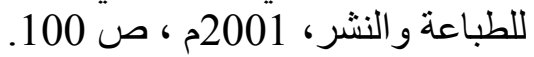

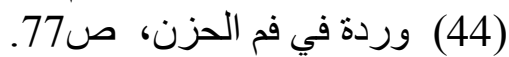

الصسورة الفنيـة في شـعر الطائيين بين الانفعال و الحس، وحيد وحيد صبحي كبَّبـة،

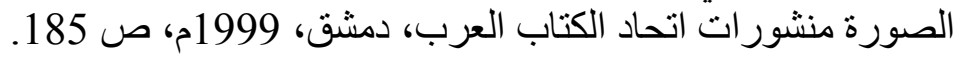

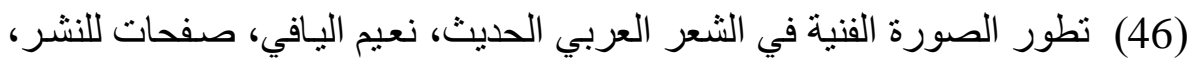

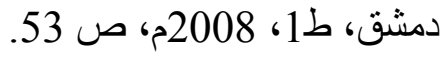

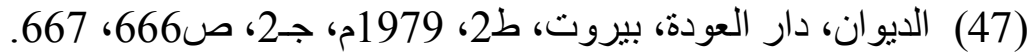

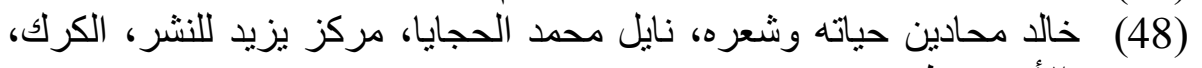

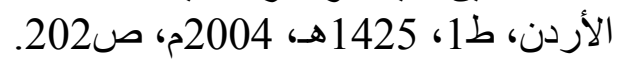

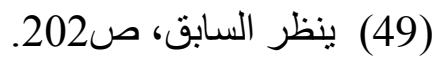

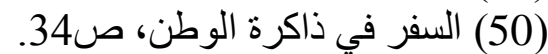

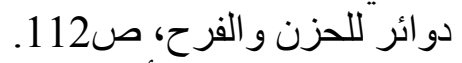

دراسات في النقد الأدبي المعاصر، داند، محمد زكي العشماوي، دار النهضة

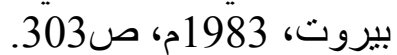
إيمان الكيلاني، دراسة أسلوبية لشعر بدر شاكر السباب، رسالة دكتوراه

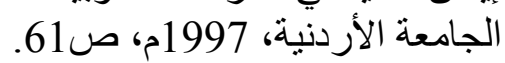

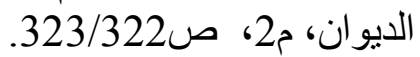

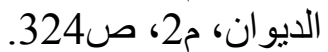

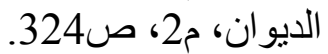
رعاية الطفل من الجنين حتى عامين، كريمان بدير، عالم الكتب، القاهرة،

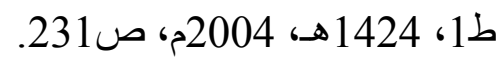
الحركة الشعرية في فلسطين المحتلة منذ عام 1948م، لهن، صالح أبو أصبع،

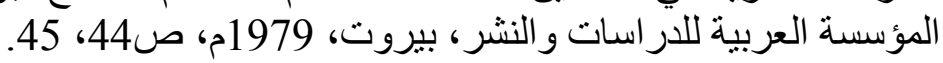
شعر غازي القضيبي، دراسة فنية، محمد الصفراني، ط1، طا، 1427هـ، 
(60) عن بناء القصيدة العربية الحديثة، علي عثري زايد، مكتبة الآداب، ط5،

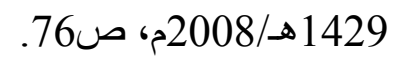

(61) الصورة الاستعارية في الثعر العربي الحديث، وجدان الصانع، المؤسسة

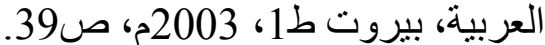

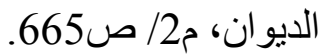

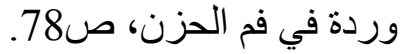

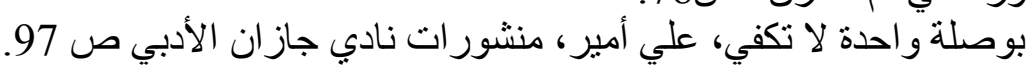

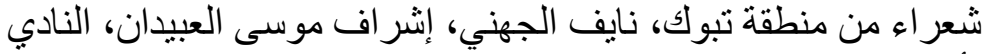

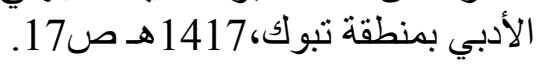

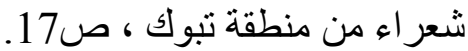

الصورة الفنية في شعر زهير بن بن أبي سلمى، عبد القادر الرباعي، مرجع

سابق، ص177 الئ.

الصورة الشعرية عند بدوي طوقان، خالد سنداوي، دار المشرق للترجمة

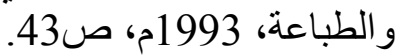

الصورة في شعر الفضول، علي عبد السلام الثرعبي، مرجع سابق،

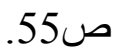

صدى الأشجان، صد5.

صدى الأشجان، صنان، صنان.

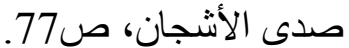

معجم البلاغة العربية، بدوي طبانة، الانه، دار العلوم، الرياض، المملكة العربية

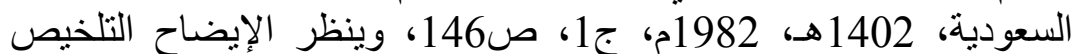
المفتاح في علوم البلاغة، عبد المتعال الصعيدي، بغية مكتبة الآداب، طبعة

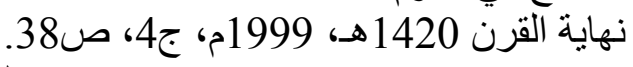

الاتجاه الإسلامي في شعر محمد بن سعد الدبل، حمد فهر جنبان الخنفري،

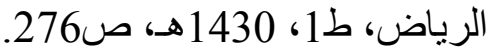

$$
\begin{aligned}
& \text { صدى الأشجان، ص38. } \\
& \text { صدى الأشجان، ص38 صنان، صنان. } \\
& \text { صدى الأشجان، ص36. }
\end{aligned}
$$

